\title{
Financial Frictions And Business Cycles in Middle-Income Countries
}

\author{
Jaime C. Guajardo \\ International Monetary Fund
}

Empirical analysis reveals three regularities among middleincome countries: consumption is highly procyclical and more volatile than output, investment is highly procyclical and three to four times as volatile as output, and real net exports are countercyclical and about three times as volatile as output. Standard dynamic stochastic general equilibrium (DSGE) small open economy models have failed to match these regularities, as they predict excessive consumption smoothing, low procyclicality and volatility of investment, and procyclical real net exports. Some studies tackle these problems by increasing the persistence of shocks (Aguiar and Gopinath, 2004 and in this volume) or by lowering the intertemporal elasticity of substitution, as when using the preferences introduced by Greenwood, Hercowitz, and Hoffman (1988) (Mendoza, 1995, 2001; Neumeyer and Perri, 2005).

This study approaches the problem by considering market imperfections relevant for middle-income countries; a limited access to the foreign capital market, identified as an external borrowing constraint; and asymmetric financing opportunities across tradable and nontradable firms, identified as a sector-specific labor-financing wedge (Caballero, 2002; Tornell and Westermann, 2003). The key parameters associated with these frictions are deduced to match selected data for Chile between 1986 and 2004, given the lack of data on the economy's net foreign asset position and sectoral financing costs. This exercise narrows the discussion to whether the cyclical properties of the deduced variables make sense according to previous

I thank useful comments on earlier versions of this paper from Harold Cole and Carlos Vegh, and from seminar and conference participants at UCLA (2003), LACEA (2003), IMF Institute (2006) and CBC (2006). The views expressed here are those of the author and should not be attributed to the IMF, its Executive Board, or its management.

Current Account and External Financing, edited by Kevin Cowan, Sebastián Edwards, and Rodrigo O. Valdés, Santiago, Chile. C 2008 Central Bank of Chile. 
studies, or whether they could be representing some other distortions not identified in the model.

I conclude that a model with an external borrowing constraint can capture the procyclical and volatile path of investment and consumption of tradable goods and produce countercyclical real net exports. However, it generates countercyclical employment and a low volatility of nontradables consumption. Introducing a countercyclical sector-specific labor-financing wedge enables the model to capture the cyclical pattern of these other variables, as well. Moreover, the cyclical properties of the key variables associated with both frictions are consistent with previous studies (Caballero, 2002; Tornell and Westermann, 2003).

An external borrowing constraint may arise from problems of enforceability and risk of default. Atkeson and Rios-Rull (1996) and Caballero and Krishnamurthy (2001) identify this friction as collateral constraints, in which part of the export sector's profits or revenues could be seized by external lenders in case of default. Eaton and Gersovitz (1981), Bulow and Rogoff (1989), Atkeson (1991), Kehoe and Levine (1993), Kocherlakota (1996), Alvarez and Jermann (2000), and Jeske (2001) consider exclusion from the external capital market as the punishment for defaulting.

Atkeson (1991) derives an external borrowing constraint in an environment in which foreign lending takes place under moral hazard and risk of repudiation. External lenders cannot observe whether borrowers are investing the borrowed funds efficiently or consuming them, and sovereign borrowers can repudiate their debt at any time. With no moral hazard and risk of repudiation, the optimal contract produces full risk sharing between domestic agents and foreign lenders. With these problems, however, foreign lenders can infer the domestic agents' allocations only after output is realized. The optimal contract reduces risk sharing, transferring part of the output risk to the domestic borrowers and thereby inducing them to invest efficiently and repay their loans.

For practical convenience, the constraint is set as the foreign lenders' requirement for domestic households to self-finance a fraction of their expenditures, $0<\Psi_{t}<1$, with their current income at each date $t$, as in Mendoza (2001). I then deduce $\Psi_{t}$ to match the path of the real net exports in Chile between 1986 and 2004. Full risk sharing is equivalent to a sufficiently procyclical $\Psi_{t}$, so that domestic agents can borrow more relative to income in bad times than in good to smooth expenditures. Partial risk sharing is equivalent to a 
less than sufficiently procyclical $\Psi_{t}$ and less expenditure smoothing. The constraint should always bind to prevent domestic agents from building up savings that would lead them to repudiate their debt.

In the simulations for Chile, the external constraint slackens when the economy receives positive shocks and tightens when it faces negative shocks, but not enough to produce full risk sharing. External financing becomes more (less) expensive during recessions (booms), increasing the procyclicality and volatility of investment and tradable goods consumption. It also reduces the procyclicality of output of export goods, as there is less reallocation of production factors across sectors, and it makes real net exports as countercyclical as in the data. However, this friction makes employment countercyclical and does not increase the volatility of nontradables consumption as much as in the data. A countercyclical labor-financing wedge would help the model match these moments by making labor demand more procyclical and volatile.

The sectoral labor-financing wedge reflects credit constraints at the firm level. They may arise from informational or enforcement problems, which could be very severe for small and medium-sized firms that lack the collateral to secure loans. Holmström and Tirole (1998) derive credit constraints for firms from moral hazard problems, while Bernanke and Gertler (1989) do it from costly state verification problems. Albuquerque and Hopenhayn (2004) and Medina (2004) derive them from enforcement problems. Kiyotaki and Moore (1997) and Caballero and Krishnamurthy (2001) represent them as collateral constraints. Tornell and Westermann (2003), using firm-level data for twenty-seven middle-income countries, find that financing is a more severe obstacle for firms in the nontradables sector, as they are mostly small and medium-sized firms that lack collateral.

Here, I set this friction as a firm's specific labor-financing wedge, which represents the lending spread each firm is charged for the credit needed to pay wages in advance of production. The spread depends on the firm's available collateral, as in Chari, Kehoe, and McGrattan (2003). ${ }^{1}$ The wedges are deduced to allow the model to replicate the path of output in the data for each sector. Consistent with previous studies, the resulting wedges are countercyclical, particularly in the nontradables sector, reflecting a lower cost of financing during

1. This specification could be capturing some other distortions in the labor market, such as sticky wages or unions (Chari, Kehoe, and McGrattan, 2003) or labor market regulations (Caballero and others, 2004). 
booms when the collateral's value increases and a higher cost during downturns when the opposite valuation effect occurs. The wedge allows the model to generate procyclical employment, as labor demand becomes more procyclical and volatile, and to increase the volatility of nontradables consumption.

Although this study does not endogenize the source of market imperfections, it presents a simulated scenario for a lower incidence of frictions to show what the economy's cyclical properties would have been if it had better access to external and domestic financing. The self-financing requirement is made more procyclical and volatile to achieve a constant borrowing constraint multiplier over time, and the cyclical fluctuations of the sector-specific labor-financing wedge are reduced. The cyclical properties of this economy would be qualitatively similar to the frictionless case; the volatility of consumption and investment would be smaller, and total work hours and the output of exportable goods would be more procyclical and volatile, resulting in procyclical and less volatile real net exports. This scenario would be welfare improving, as households value a smoother path of consumption over time.

The paper is organized as follows. Section 1 presents a discussion of the empirical evidence and related literature. Section 2 presents the model and simulations for the standard friction-less economy. I then derive variations of the base model: section 3 presents the model and simulations for an externally credit constrained economy, section 4 for an economy with asymmetric financing opportunities, and section 5 for an economy that features both frictions. Section 6 concludes.

\section{Empirical Evidence and Related Literature}

This section compares the moments of middle-income countries and small developed economies to highlight the particular features of middle-income countries. Table 1 presents statistics for output, consumption, investment, real net exports, and the terms of trade for twenty-seven middle-income countries and the average of sixteen small developed economies for annual data between 1980 and 2004. Each variable corresponds to the log deviation from its trend, which was obtained using the Hodrick-Prescott filter with a smoothing parameter of 100 . The statistics presented are the first-order autocorrelation and standard deviation of gross domestic product (GDP) and the crosscorrelations and standard deviations of consumption, investment, real net exports and terms of trade relative to GDP. 


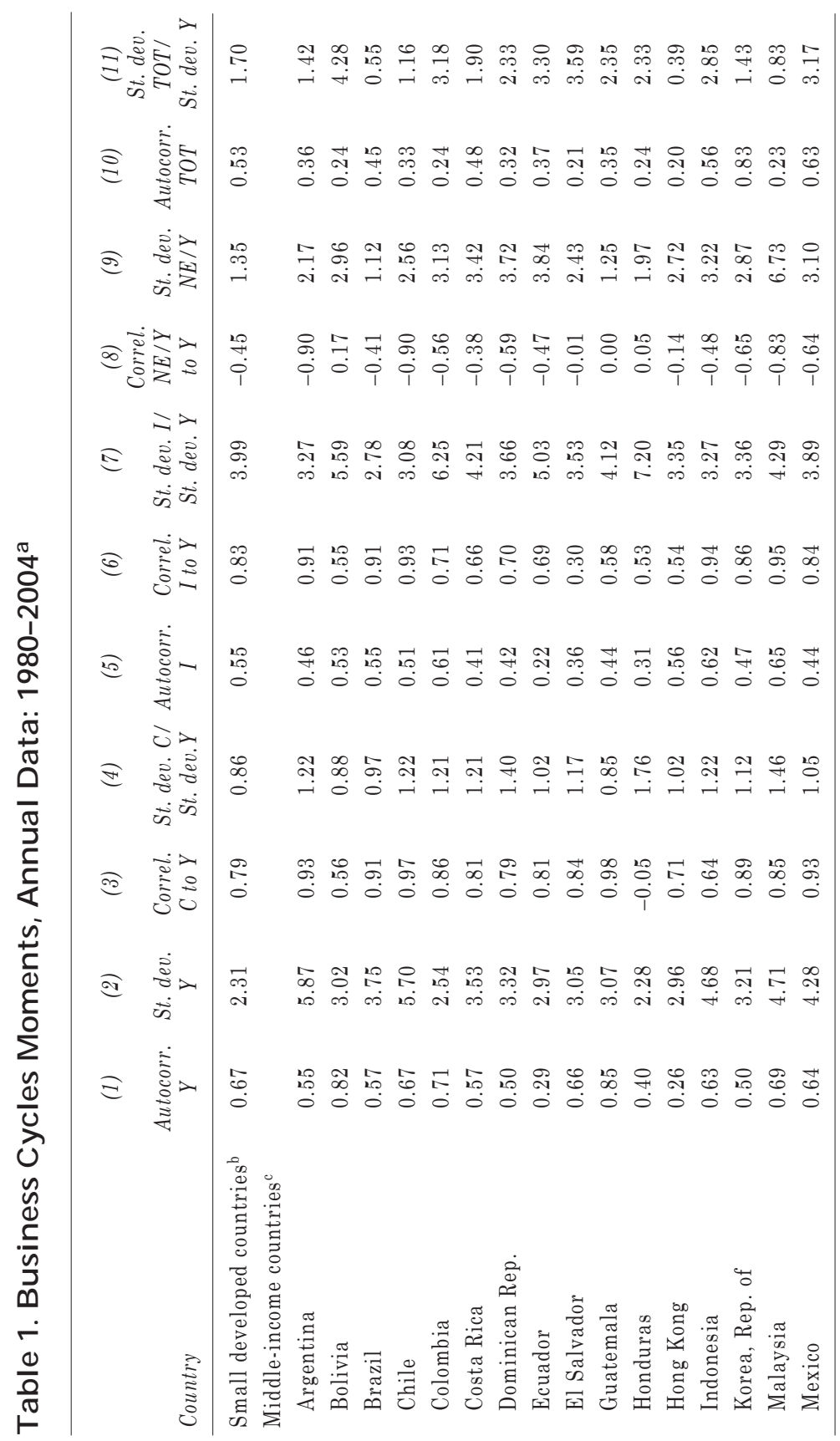




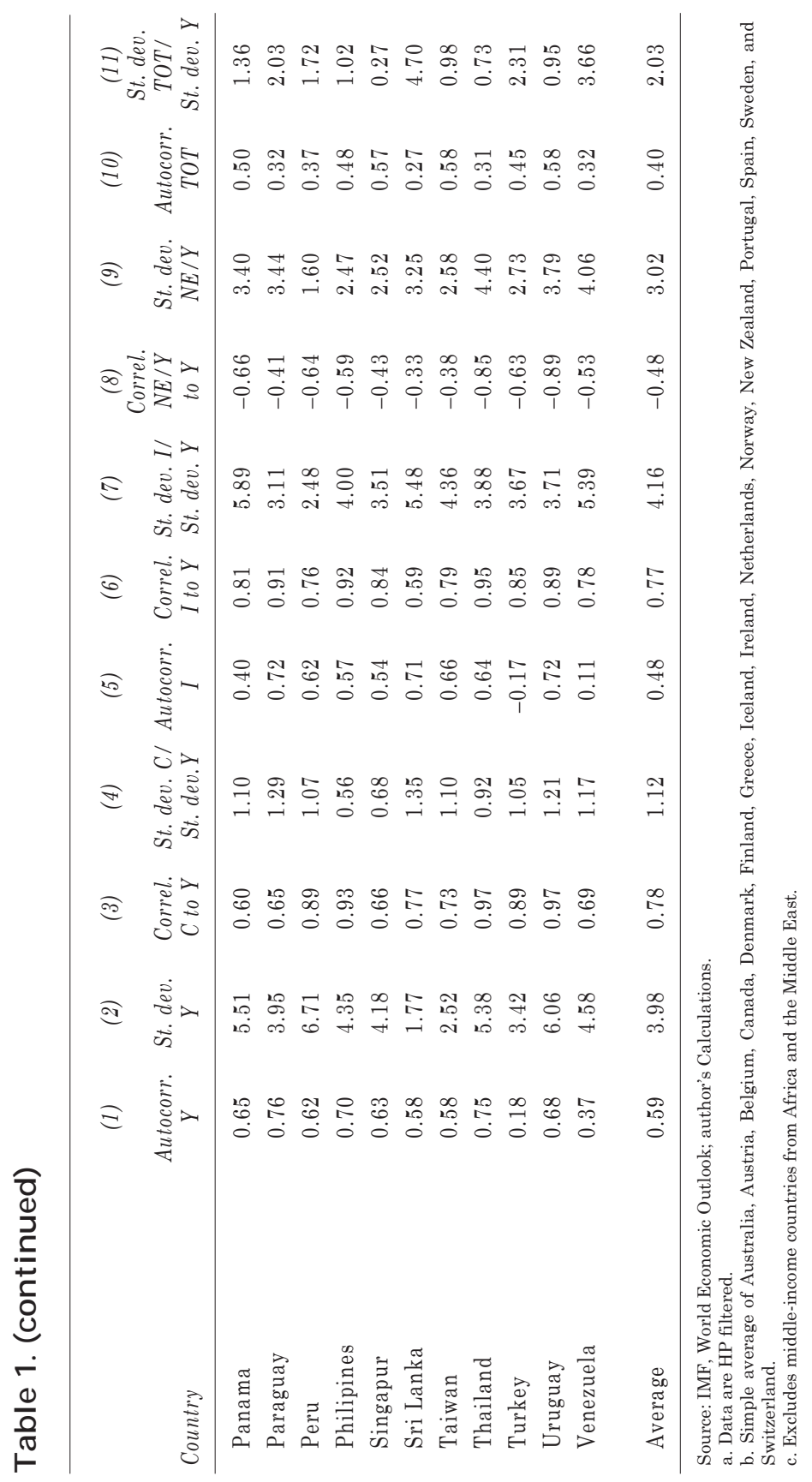


The first distinctive feature is that GDP is almost twice as volatile in the middle-income countries as in the small developed economies, but only slightly less persistent. Second, while investment is as volatile relative to output in both groups of countries, consumption and real net exports are significantly more volatile relative to output in middleincome countries than in small developed economies. Third, all three expenditure items present roughly the same contemporaneous crosscorrelation with GDP in the two groups of countries. These findings are robust to different data frequency. Aguiar and Gopinath (2004) present similar evidence at a quarterly frequency for a smaller sample of small developed economies and middle-income countries. They find the same differences in volatility and similarities in correlations with output, except for the ratio of real net exports to GDP, which is more countercyclical in middle-income countries than in small developed economies at quarterly frequency.

One concern with the moments presented in table 1 is whether they are representative of normal business cycles fluctuations in middleincome countries or are biased as a result of crises. Although table 1 does not abstract from periods of crisis, Tornell and Westermann (2002) argue that the typical lending booms that characterize middle-income countries business cycles commonly end in a soft landing with the same moments as in crisis periods, but with less volatility. To avoid this problem, this paper studies the case of Chile between 1986 and 2004, abstracting from its last crisis in 1982.

Earlier studies reproduce the high volatility of consumption and real net exports in middle-income countries by lowering the intertemporal elasticity of substitution, by increasing the shocks' persistence, or by considering frictions in the access to foreign and domestic financing. With regard to the former, Mendoza $(1995,2001)$ and Neumeyer and Perry (2005), for Mexico and Argentina, respectively, solved the problem by using Greenwood, Hercowitz, and Hoffman's (1988) preferences or by lowering the intertemporal elasticity of substitution. Greenwood, Hercowitz, and Hoffman's (1988) preferences make the labor-leisure decision dependent only on real wages, which makes work hours, consumption, and investment more procyclical and volatile, while real net exports become countercyclical. A lower intertemporal elasticity of substitution produces similar results.

Some empirical studies estimate a lower intertemporal elasticity of substitution for middle-income countries than for small developed economies (Ostry and Reinhart, 1992; Barrionuevo, 1993), but Domeij (2006) shows that such estimates would be biased downward 
if borrowing constraints are ignored in the estimation. He applies standard econometric methods to artificial data constructed for credit-constrained agents, but ignores the constraints in the estimation. This results in an estimated intertemporal elasticity of substitution 50 percent lower than the true elasticity with which the data were built.

With regard to increasing the shocks' persistence, Aguiar and Gopinath (2004 and in this volume) introduce a permanent shock to the trend growth rate of productivity into an otherwise standard DSGE small open economy model, to replicate the cyclical regularities of Mexico. This model could replicate the high volatility of consumption and real net exports observed in middle-income countries, but it relies largely on the strong persistence of the shock to the trend growth rate of productivity, which creates larger procyclical fluctuations in consumption and investment and larger countercyclical fluctuations in real net exports than do shocks to productivity around a trend.

There is no evidence that foreign or domestic shocks are, in fact, more persistent in middle-income countries than in small developed economies. Although there are no data on total factor productivity across countries, the cyclical properties of output and investment offer clues. More persistent productivity shocks would presumably result in more persistent fluctuations in output and investment, as the marginal productivity of capital varies directly with the shock. However, column 1 in table 1 shows that output is slightly less persistent in the middle-income countries than in the small developed economies, while columns 5 and 6 show that investment is less persistent and procyclical in the middle-income countries. For foreign shocks, columns 10 and 11 show that the terms of trade are less persistent, but more volatile in the middle-income countries, while the foreign interest rate shocks should be as persistent and volatile across groups as long as the risk premium is endogenous.

Finally, with regard to frictions in the access to foreign and domestic financing, Caballero (2000) studies the source of volatility in three Latin American middle-income countries: namely, Argentina, Chile, and Mexico. He finds that these economies are weak in their links with the foreign capital market and in the development of their domestic financial markets. These frictions can account for a large share of the fluctuations and crises in modern Latin America, either directly or by leveraging a variety of shocks. Tornell and Westermann $(2002,2003)$ provide evidence of asymmetric financing opportunities 
across tradable and nontradable firms for a sample of twenty-seven middle-income countries. Estimating an ordered probit model, they find that financing was a more severe obstacle for the nontradable firms, as they were mostly small and medium-sized firms that lack the collateral to secure loans.

Caballero and Krishnamurthy (2001) analyze the interaction of these two frictions in a stylized model with two types of collateral constraints: firms in the domestic economy have limited borrowing capacity from foreign investors and from each other. Their interaction produced two suboptimal allocations. First, disintermediation, by which a fire sale of domestic assets causes banks to fail, triggered a reallocation of resources across firms and resulted in wasted international collateral. Second, a dynamic effect results when firms with limited domestic collateral and a binding international collateral constraint do not take adequate precautions against adverse shocks, thereby increasing their severity.

This paper takes Chile as a case study for three reasons. First, it presents roughly the same cyclical moments as other middleincome countries, although with less volatility. Comparing table 2 with columns 1 through 9 in table 1 reveals that the first-order autocorrelation of output is roughly the same in Chile as in other middle-income countries, while the standard deviation of output is about half the average of middle-income countries. Consumption and investment are both a little more procyclical in Chile, but as volatile relative to output, while real net exports are more countercyclical and a little less volatile. Second, Chile is frequently cited in the literature for its disciplined economic policy, which makes it reasonable to abstract from monetary and fiscal policy shocks. This reduces the model to a simple exchange-production economy, similar to that used by Aguiar and Gopinath (2004 and in this volume), Mendoza (1995, 2001), and Neumeyer and Perry (2005). Third, Caballero (2000, 2002) finds an active role of the two financial frictions studied here in Chile's business cycles in the 1990s. With regard to the limited access to the foreign capital market, he shows that in 1999 consumption and the current account deficit fell more than what could be explained by the negative terms-of-trade shock, in part because of the decline in capital inflows. With regard to domestic financing opportunities, he shows that domestic banks reacted to the shock by slowing down private loans, even though domestic deposits were growing fast. They substituted private domestic loans with public debt and external assets, and they allocated a higher fraction of their credit to large firms, reducing the 
access to credit of small and medium-sized firms. Large firms, most of them in the tradables sector, could substitute their financial needs in the domestic market, while small and medium-sized firms, most of them in the nontradables sector, could not do so.

Table 2. Data Moments ${ }^{a}$

(1) (2) (3) (4)

\begin{tabular}{lccccc} 
Variable & $x$ & $\rho\left(x_{t}, y_{t}\right)$ & $\rho\left(x_{t}, y_{t-1}\right)$ & $\sigma(x)$ & $\sigma(x) / \sigma(y)$ \\
\hline Aggregate output & $y$ & 1.00 & 0.59 & 2.29 & 1.00 \\
Output exportables & $y^{x}$ & 0.84 & 0.39 & 1.78 & 0.78 \\
Output nontradables & $y^{n}$ & 0.98 & 0.61 & 2.80 & 1.22 \\
Aggregate consumption & $c$ & 0.95 & 0.69 & 2.66 & 1.16 \\
Consumption importables & $c^{m}$ & 0.25 & 0.45 & 4.98 & 2.17 \\
Consumption nontradables & $c^{n}$ & 0.98 & 0.61 & 2.80 & 1.22 \\
Investment & $i$ & 0.80 & 0.44 & 8.50 & 3.71 \\
Investment exportables & $i^{x}$ & n.a. & n.a. & n.a. & n.a. \\
Investment nontradables & $i^{n}$ & n.a. & n.a. & n.a. & n.a. \\
Real net exports & $n x$ & -0.74 & -0.41 & - & 2.55 \\
Nominal net exports & $n n x$ & - & - & - & - \\
Work hours & $h$ & 0.40 & 0.12 & 1.78 & 0.78 \\
Work hours exportables & $h^{x}$ & -0.09 & -0.30 & 2.05 & 0.89 \\
Work hours nontradables & $h^{n}$ & 0.53 & 0.25 & 1.96 & 0.85 \\
Aggregate capital & & 0.33 & 0.68 & 2.88 & 1.26 \\
Capital exportables & $k^{x}$ & 0.43 & 0.75 & 3.06 & 1.34 \\
Capital nontradables & $k^{n}$ & 0.24 & 0.60 & 2.80 & 1.22 \\
\hline
\end{tabular}

Source: Central Bank of Chile; author's calculations.

n.a. Not available.

a. Data are HP filtered.

This study seeks to evaluate quantitatively, in a DSGE framework, whether considering these two frictions in an otherwise standard small open economy model can replicate the high volatility of consumption and countercyclicality of net exports observed in middle-income countries. The model is calibrated and simulated for shocks to the terms of trade, foreign interest rate, and total factor productivity between 1986 and 2004. I begin with a frictionless version of the model and then incorporate each friction separately into the model to quantify its specific role in the domestic cycles. Finally, a model that features both frictions is simulated. 


\section{Model 1: Frictionless Small Open Economy}

Consider a small open economy that is perfectly integrated with the world in goods, but faces an aggregate upward-sloping supply of external funds:

$$
R_{t}=R_{t}^{*}+\eta\left(\bar{b}-b_{t}\right),
$$

where $R_{t}$ is the domestic rate of return, $R_{t}{ }^{*}$ is the foreign rate of return, $b_{t}$ is the net foreign asset position, $\bar{b}$ is the level of foreign assets at which the risk premium is zero, and $\eta$ is the elasticity of the risk premium to $b_{t} \cdot R_{t}^{*}$ is stochastic according to

$$
R_{t}^{*}=\exp \left(\varepsilon_{t}^{R}\right) R^{*},
$$

where $R^{*}$ is its unconditional mean and $\varepsilon_{t}^{R}$ its first-order autoregressive shock:

$\varepsilon_{t+1}^{R}=\rho^{R} \varepsilon_{t}^{R}+v_{t+1}^{R}$,

with $E\left(v_{t+1}^{R}\right)=0$ and $V\left(v_{t+1}^{R}\right)=\sigma_{R}^{2}$.

This is not exactly a frictionless setup, in which $R_{t}=R_{t}{ }^{*}$ at each date $t$, because when the model is log-linearized around the steady state, it yields a unit root process for consumption, work hours, investment, net exports, and net foreign assets (see Correia, Neves, and Rebelo, 1995). To have a unique steady state, it is necessary to anchor the level of external debt in equilibrium. This can be done by setting an upward-sloping supply of external funds, a cost function of adjusting the external asset portfolio, or an endogenous discount factor. Schmitt-Grohé and Uribe (2003) show that all of these three forms yield the same first and second moments. I chose the first to be consistent with the later specifications, and I kept $\eta$ small to make the model a good approximation of the frictionless setup.

There are three goods in this economy: an exportable good $(X)$, an importable good $(M)$, and a nontradable good $(N)$. The two production factors are labor $(h)$ and capital $(k)$. The home economy produces $X$ and $N$ goods, using $h$ and $k$ inputs. Capital is sector specific, and labor 
moves freely across sectors. The law of one price holds for both tradable goods. The external price of $M$ is normalized to one and assumed constant, while the external price of $X$ is stochastic, according to the following process:

$P_{t}^{X}=\exp \left(\varepsilon_{t}^{P^{X}}\right) P^{X *}$,

where $P^{X^{*}}$ is its unconditional mean and $\varepsilon_{t}^{P^{X}}$ the first-order autoregressive shock:

$\varepsilon_{t+1}^{P^{X}}=\rho^{P^{X}} \varepsilon_{t}^{P^{X}}+v_{t+1}^{P^{X}}$,

with $E\left(v_{t+1}^{P^{X}}\right)=0$ and $V\left(v_{t+1}^{P^{X}}\right)=\sigma_{P^{X}}^{2}$.

There are two types of domestic agents: households and firms. Households own the firms, consume the $N$ good, buy the $M$ good for consumption and investment, and supply $h$ and $k$ to the firms. They are the only ones with access to foreign financing. There are two firms, the export firm and the nontradable firm; both use $h$ and $k$ to produce their goods. The economy follows a balanced growth path at a growth rate of $(\gamma-1)$, and population is constant. In the following, the model is set in stationary form.

\subsection{Households}

Households maximize their lifetime utility according to equation (6):

$U=E_{0}\left\{\sum_{t=0}^{\infty} \frac{\beta^{* t}\left[c_{t}^{\alpha}\left(1-h_{t}\right)^{1-\alpha}\right]^{1-\sigma}}{1-\sigma}\right\}$,

where $\beta^{*}=\beta \gamma^{\alpha(1-\sigma)}, \beta$ is the discount factor, $h_{t}$ the normalized work hours, and $c_{t}$ a constant elasticity of substitution (CES) aggregation of consumption of importable $\left(c_{t}^{M}\right)$ and nontradable $\left(c_{t}^{N}\right)$ goods:

$c_{t}=\left[\varpi c_{t}^{M \rho}+(1-\varpi) c_{t}^{N \rho}\right]^{\frac{1}{\rho}}$, 
where $1 / \sigma$ and $1 /(1-\rho)$ are the intertemporal elasticity of substitution and the elasticity of substitution between $M$ and $N$, respectively. Since the foreign bonds and capital are the only assets in this economy, asset markets are incomplete and the economy's wealth varies with the state of nature. The households flow budget constraint is

$w_{t} h_{t}+q_{t}^{X} k_{t}^{X}+q_{t}^{N} k_{t}^{N}+R_{t} b_{t}=c_{t}^{M}+P_{t}^{N} c_{t}^{N}+i_{t}^{X}+i_{t}^{N}+\gamma b_{t+1}$,

where $w_{t}$ is the wage rate, $P_{t}^{N}$ the relative price of $N$ to $M$ goods, and $k_{t}^{j}, i_{t}^{j}$, and $q_{t}^{j}$ are capital, investment, and the rental rate of capital in sector $j$, respectively. Investment is used to replace depreciated capital, accumulate new capital, and cover the capital adjustment costs, according to the following law of motion:

$$
\gamma k_{t+1}^{j}=(1-\delta) k_{t}^{j}+i_{t}^{j}-\frac{\theta}{2}\left(i_{t}^{j}\right)^{2}
$$

for $j=X, N$, where $\delta$ is the depreciation rate and $\theta$ the coefficient on the quadratic adjustment costs. Households choose the sequence $\left\{c_{t}^{M}, c_{t}^{N}, h_{i}\right.$, $\left.i_{t}^{X}, i_{t}^{N}, k_{t+1}^{X}, k_{t+1}^{N}, b_{t+1}\right\}\left.\right|_{t=0} ^{\infty}$, to maximize equation (6), subject to equations (8) and (9). Their first-order conditions are as follows:

$$
\begin{aligned}
& \alpha \varpi\left[\varpi c_{t}^{M \rho}+(1-\varpi) c_{t}^{N \rho}\right]^{\frac{\alpha}{\rho}(1-\sigma)-1}\left(1-h_{t}\right)^{(1-\alpha)(1-\sigma)} c_{t}^{M(\rho-1)}=\lambda_{t} ; \\
& \alpha(1-\varpi)\left[\varpi c_{t}^{M \rho}+(1-\varpi) c_{t}^{N \rho}\right]^{\frac{\alpha}{\rho}(1-\sigma)-1}\left(1-h_{t}\right)^{(1-\alpha)(1-\sigma)} c_{t}^{N(\rho-1)}=P_{t}^{N} \lambda_{t} ; \\
& (1-\alpha)\left[\varpi c_{t}^{M \rho}+(1-\varpi) c_{t}^{N \rho}\right]^{\frac{\alpha}{\rho}(1-\sigma)}\left(1-h_{t}\right)^{\alpha(\sigma-1)-\sigma}=\lambda_{t} w_{t} ; \\
& \phi_{t}^{X}=\lambda_{t}+\phi_{t}^{X} \theta i_{t}^{X} \\
& \phi_{t}^{N}=\lambda_{t}+\phi_{t}^{N} \theta i_{t}^{N} \\
& \gamma \phi_{t}^{X}=\beta E_{t}\left[\lambda_{t+1} q_{t+1}^{X}+\phi_{t+1}^{X}(1-\delta)\right]
\end{aligned}
$$


$\gamma \phi_{t}^{N}=\beta E_{t}\left[\lambda_{t+1} q_{t+1}^{N}+\phi_{t+1}^{N}(1-\delta)\right]$

$\gamma \lambda_{t}=\beta E_{t}\left(\lambda_{t+1} R_{t+1}\right) ;$ and

$E_{t}\left[\lim _{t \rightarrow \infty} \beta^{t} \lambda_{t}\left(k_{t+1}^{X}+k_{t+1}^{N}+b_{t+1}\right)\right]=0 ;$

where $\lambda_{t}, \varphi_{t}^{X}$, and $\varphi_{t}^{N}$ are the Lagrange multipliers on equations (8) and (9), respectively.

\subsection{Firms}

Both firms have Cobb-Douglas constant-return-to-scale technologies and choose $\left.\left\{h_{t}^{f j}, k_{t}^{f j}\right\}\right|_{t=0} ^{\infty}$ to maximize profits, with $j=X, N$. The first-order conditions for the nontradable firm are

$$
\begin{aligned}
& w_{t}=\left(1-\alpha_{N}\right) P_{t}^{N} \exp \left(\varepsilon_{t}^{N}\right)\left(k_{t}^{f N}\right)^{\alpha_{N}}\left(h_{t}^{f N}\right)^{-\alpha_{N}} \text { and } \\
& q_{t}^{N}=\alpha_{N} P_{t}^{N} \exp \left(\varepsilon_{t}^{N}\right)\left(h_{t}^{f N}\right)^{\left(1-\alpha_{N}\right)}\left(k_{t}^{f N}\right)^{\left(\alpha_{N}-1\right)} ;
\end{aligned}
$$

while the first-order conditions for the export firm are

$$
\begin{aligned}
& w_{t}=\left(1-\alpha_{X}\right) P_{t}^{X} \exp \left(\varepsilon_{t}^{X}\right)\left(k_{t}^{f X}\right)^{\alpha_{X}}\left(h_{t}^{f X}\right)^{-\alpha_{X}} \text { and } \\
& q_{t}^{X}=\alpha_{X} P_{t}^{X} \exp \left(\varepsilon_{t}^{X}\right)\left(h_{t}^{f X}\right)^{\left(1-\alpha_{X}\right)}\left(k_{t}^{f X}\right)^{\left(\alpha_{X}-1\right)},
\end{aligned}
$$

where $\varepsilon_{t}^{j}$ is the productivity shock in each sector $j=X, N$, respectively. The shocks follow a first-order autoregressive process:

$$
\varepsilon_{t+1}^{j}=\rho^{j} \varepsilon_{t}^{j}+v_{t+1}^{j}
$$

with $E\left(v_{t+1}^{j}\right)=0$ and $V\left(v_{t+1}^{j}\right)=\sigma_{j}^{2}$. 


\subsection{Competitive Equilibrium}

Given $b_{0}, k_{0}^{X}$, and $k_{0}^{N}$ and shocks' processes $\left(\varepsilon_{t}^{R}, \varepsilon_{t}^{P_{X}}, \varepsilon_{t}^{X}, \varepsilon_{t}^{N}\right)$, a competitive equilibrium corresponds to sequences of allocations $\left\{c_{t}^{M}\right.$, $\left.c_{t}^{N}, h_{t}, i_{t}^{X}, i_{t}^{N}, k_{t+1}^{X}, k_{t+1}^{N}, b_{t+1}\right\}\left.\right|_{t=0} ^{\infty},\left.\left\{h_{t}^{f X}, h_{t}^{f N}, k_{t}^{f X}, k_{t}^{f N}\right\}\right|_{t=0} ^{\infty}$ and prices $\left\{P_{t}^{X}\right.$, $\left.P_{t}^{N}, q_{t}^{X}, q_{t}^{N}, w_{t}, R_{t}\right\}\left.\right|_{t=0} ^{\infty}$ such that:

-Given $b_{0}, k_{0}^{X}, k_{0}^{N}$, prices, and shocks' processes, $\left\{c_{t}^{M}, c_{t}^{N}, h_{t}, i_{t}^{X}\right.$, $\left.i_{t}^{N}, k_{t+1}^{X}, k_{t+1}^{N}, b_{t+1}\right\}\left.\right|_{t=0} ^{\infty}$ solve the households' problem;

-Given prices and shocks' processes, $\left.\left\{h_{t}^{f X}, k_{t}^{f X}\right\}\right|_{t=0} ^{\infty}$ solve firm X's problem;

—Given prices and shocks' processes, $\left.\left\{h_{t}^{f N}, k_{t}^{f N}\right\}\right|_{t=0} ^{\infty}$ solve firm N's problem;

-Market-clearing conditions are satisfied: $c_{t}^{N}=y_{t}^{N}, k_{t}^{X}=k_{t}^{f X}$, $k_{t}^{N}=k_{t}^{f N}$, and $h_{t}=h_{t}^{f X}+h_{t}^{f N} ;$ and

-The resource constraint is satisfied: $R_{t} b_{t}+P_{t}^{X} Y_{t}^{X}-c_{t}^{M}-i_{t}^{X}-i_{t}^{N}-\gamma b_{t+1}=0$.

\subsection{Steady State and Calibration}

The parameters are calibrated to match Chile's average macroeconomic ratios between 1986 and 2004. Table 3 presents the parameters, together with the ratios in the data and in the model in steady-state. The risk premium elasticity, $\eta$, is 0.001 as in SchmittGrohé and Uribe (2003), net foreign assets are -19 percent of GDP, and $\bar{b}$ is 8.8 percent of GDP, to yield a spread $R_{t}-R_{t}^{*}$ of 200 basis points. The parameter $\gamma$ is equal to 1.056, or one plus the average growth of GDP, while $\beta$ is 0.94 in the steady state according to equation (17).

To calibrate the other parameters, it is necessary to construct the sectoral series of output and hours of work. For output, the sectoral series of GDP from national accounts were allocated as exportable or nontradable goods as in Stockman and Tesar (1995) and Mendoza (1995). The export sector's GDP was defined as the sum of GDP in the mining, agriculture, forestry, fishery, and manufacturing sectors, equivalent to 36 percent of GDP, while the nontradables sector's GDP corresponds to the sum of GDP of the wholesale and retail trade, construction, electricity, gas, and water, financial services, housing, personal services, public administration and transport, storage, and communication sectors, equivalent to 64 percent of 


\section{Table 3. Calibration and Macroeconomic Aggregates}

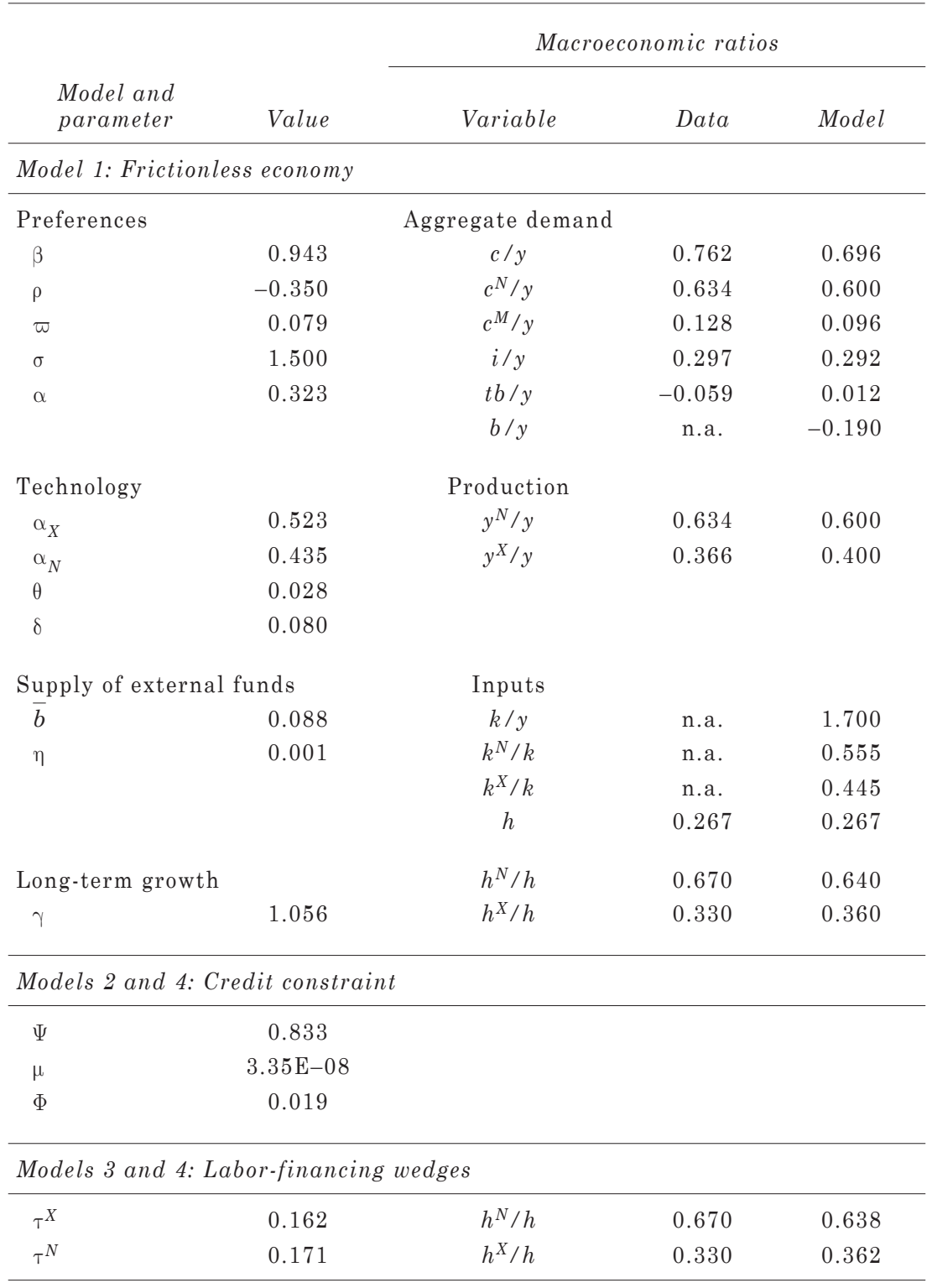

Source: Central Bank of Chile; National Institute of Statistics. n.a. Not available. 
GDP. A similar aggregation was used to allocate employment across sectors. Employment in the export sector is the sum of employees in the mining, agriculture, hunting and fishery, and manufacturing sectors, equivalent to 33 percent of total employment, while in the nontradables sector it is the sum of employees in the construction, electricity, gas and water, trade, transport and communication, financial services, and social services sectors, equivalent to 67 percent of total employment.

Consumption of the nontradable good is equal to nontradable output, while consumption of importable goods is equal to the rest of total consumption. In steady state, the current account balance has to be equal to zero, whereas it is in deficit in the data, so I had to adjust some ratios in the model to calibrate a consistent steady state. The ratio of exportable GDP to total GDP was increased from 0.37 in the data to 0.40 in the model; the ratio of investment was reduced from 0.30 in the data to 0.29 in the model; and the ratio of importable goods consumption was reduced from 0.13 in the data to 0.10 in the model. As a result, the ratio of real net exports to GDP was increased from -0.06 in the data to 0.01 in the model.

In line with the adjustments in output, the share of employment in the export sector was increased from 0.33 in the data to 0.36 in the model, and the nontradable share was reduced from 0.67 in the data to 0.64 in the model. The prices of $X$ and $N$ relative to $M$ were both set equal to one in steady state. Next, $\sigma$ and $\rho$ were set as in Mendoza (1995) for the industrialized economies ${ }^{2}$, while $\alpha, \bar{w}, \lambda, \varphi^{X}$, and $\varphi^{N}$ were calibrated from equations (10) to (14), respectively. The shares $\alpha_{X}$ and $\alpha_{N}$ were calibrated to generate the sectoral allocation of labor in the model and an overall capital income share of 0.46 , as estimated by Gallego, Schmidt-Hebbel, and Servén (2005) and García and others (2005). Table 3 shows that the calibration is consistent with the macroeconomic ratios in the data, except for the adjustments made to achieve a zero current account balance in steady state.

\subsection{Simulations}

The model is simulated for exogenous shocks to the terms of trade, foreign real interest rate, and productivity in the export and

2. I chose the benchmark parameters for industrialized economies because the parameters for the developing economies can be biased as a result of more severe credit constraints ignored in the estimation. 
nontradables sectors. The foreign real interest rate is defined as the U.S. federal funds rate minus ex post inflation; the terms of trade is the ratio of prices of exports to imports of goods and services. Total factor productivity for each sector corresponds to the Solow residual, for which I used the sectoral series of output described in the previous section, while the aggregate and sectoral series of work hours and capital were constructed.

Total work hours were built using total employment from the National Institute of Statistics and average hours worked per employee from the International Labor Organization (ILO). They were normalized taking the average hours worked times the number of employees, divided by the potential working time of the working-age population. Its sectoral allocation was built assuming that labor is freely mobile across sectors and that both sectors present Cobb-Douglas production functions with constant return to scale, so that its marginal productivity is equal across sectors according to equation (24):

$\frac{h_{t}^{N}}{h_{t}^{X}}=\frac{\left(1-\alpha_{N}\right) P_{t}^{N} y_{t}^{N}}{\left(1-\alpha_{X}\right) P_{t}^{X} y_{t}^{X}}$.

The aggregate capital stock $\left(k_{t}\right)$ was estimated using the following law of motion:

$$
\gamma k_{t+1}=(1-\delta) k_{t}+i_{t}-\frac{\theta}{2} i_{t}^{2},
$$

where $k_{t}$ and $i_{t}$ are aggregate capital and investment, respectively. For its sectoral allocation, capital was assumed to be sector specific, but investment freely mobile across sectors. I used a three-step procedure. First, the allocation of freely mobile capital was obtained, equating its marginal productivity across sectors (equation 26 ):

$\frac{k_{t}^{N}}{k_{t}^{X}}=\frac{\alpha_{N} P_{t}^{N} y_{t}^{N}}{\alpha_{X} P_{t}^{X} y_{t}^{X}}$.

Second, the implicit series of investment were derived from these allocations, considering capital as sector specific. Third, a nonnegativity condition for investment in each sector was verified, with the finding that the freely mobile allocation is consistent 
with positive investment in both sectors. Then, given that sectorspecific capital would only create one-period discrepancies in the sectoral allocation of capital relative to freely mobile capital, I decided to take the latter. ${ }^{3}$

Figure 1, panel A, presents all four shocks in log deviation from their Hodrick-Prescott (HP) trend between 1986 and 2004. Table 4 shows that the autocorrelation of the two productivity shocks and the terms of trade is low, ranging between 0.3 and 0.4. Only the foreign real interest rate is more persistent. The terms-of-trade shocks are the most volatile, about three times as volatile as output, while both productivity shocks and foreign real interest rate are less volatile than output. Finally, the innovations to all four shocks are positively crosscorrelated among them, particularly between both productivity shocks and between the terms of trade and the foreign real interest rate.

\section{Figure 1. Chile: Domestic and External Shocks and Financial Frictions}

A. Exogenous shocks for models 1, 2, 3, and 4

Real foreign interest rate

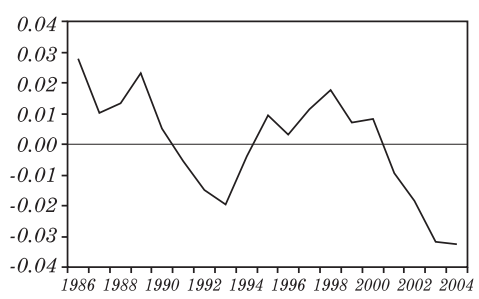

Productivity shock, exportables

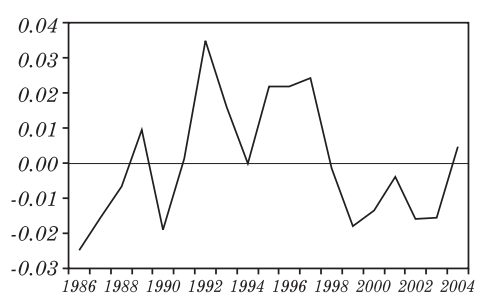

Terms of trade

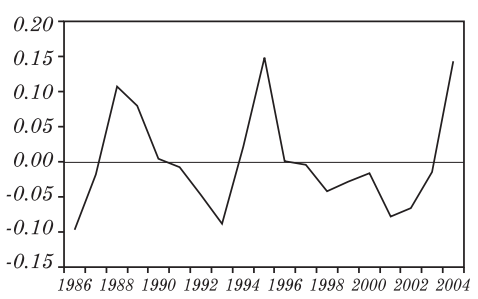

Productivity shock, nontradables

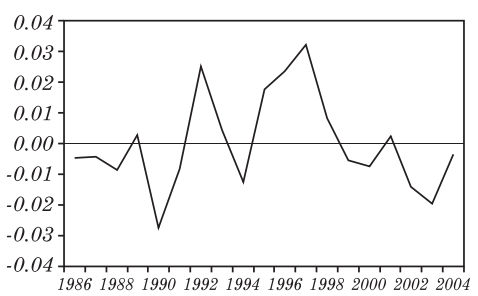

3. This would be optimal if domestic agents could foresee future shocks and invest accordingly. 


\section{Figure 1. Chile: (continued)}

B. Self-financing requirement and external borrowing constraint multiplier for model 2

Self-financing

requirement

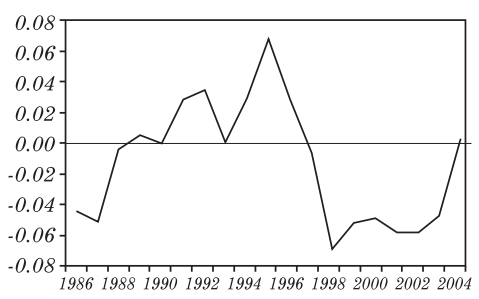

Borrowing constraint multiplier

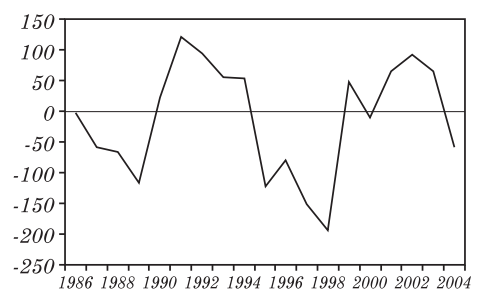

C. Labor-financing wedges for model 3

Exportable firm's labor-financing wedge

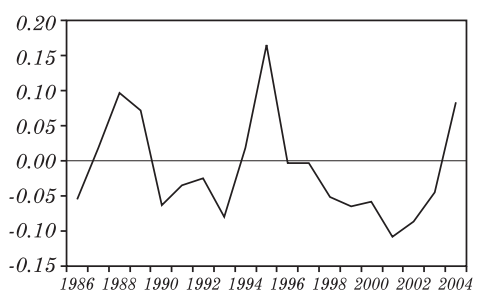

Nontradable firm's labor-financing wedge

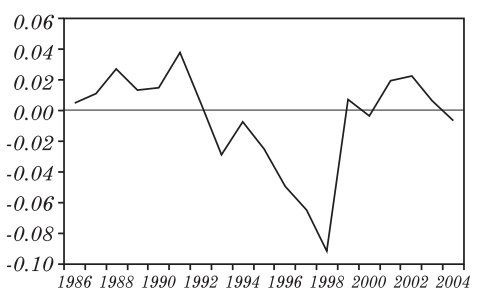

Source: Author's computations.

The model was log-linearized, so the variables represent log deviations from their steady-state values. Table 5 presents the data moments in columns 1-4 and model 1's simulated moments in columns 5-8. Model 1 predicts excessive consumption smoothing of importable and nontradable goods, a lower volatility and procyclicality of investment, and procyclical, instead of countercyclical, real net exports.

Consumption smoothing results in a less procyclical and less volatile nontradable output, but in a more procyclical and more volatile exportables output. In response to the terms-of-trade shocks (the main drivers of the domestic cycles), work hours are reallocated from the nontradables sector to the export sector for positive shocks and vice versa for negative shocks. Thus, hours of work in the export sector are highly procyclical, contrasting with the highly countercyclical employment in the nontradables sector. At the same time, aggregate work hours become more volatile and procyclical. 


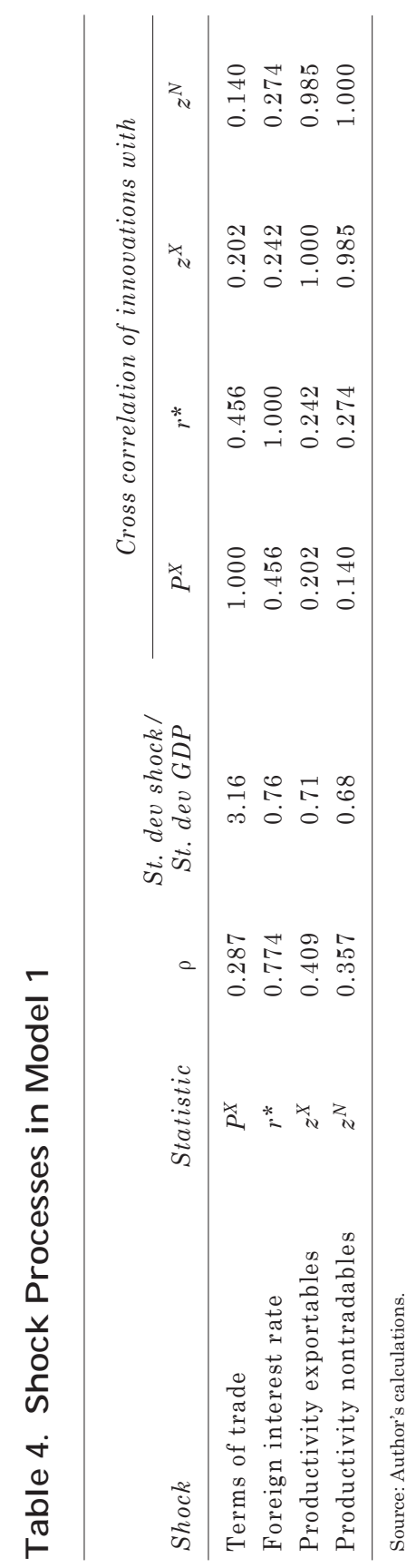




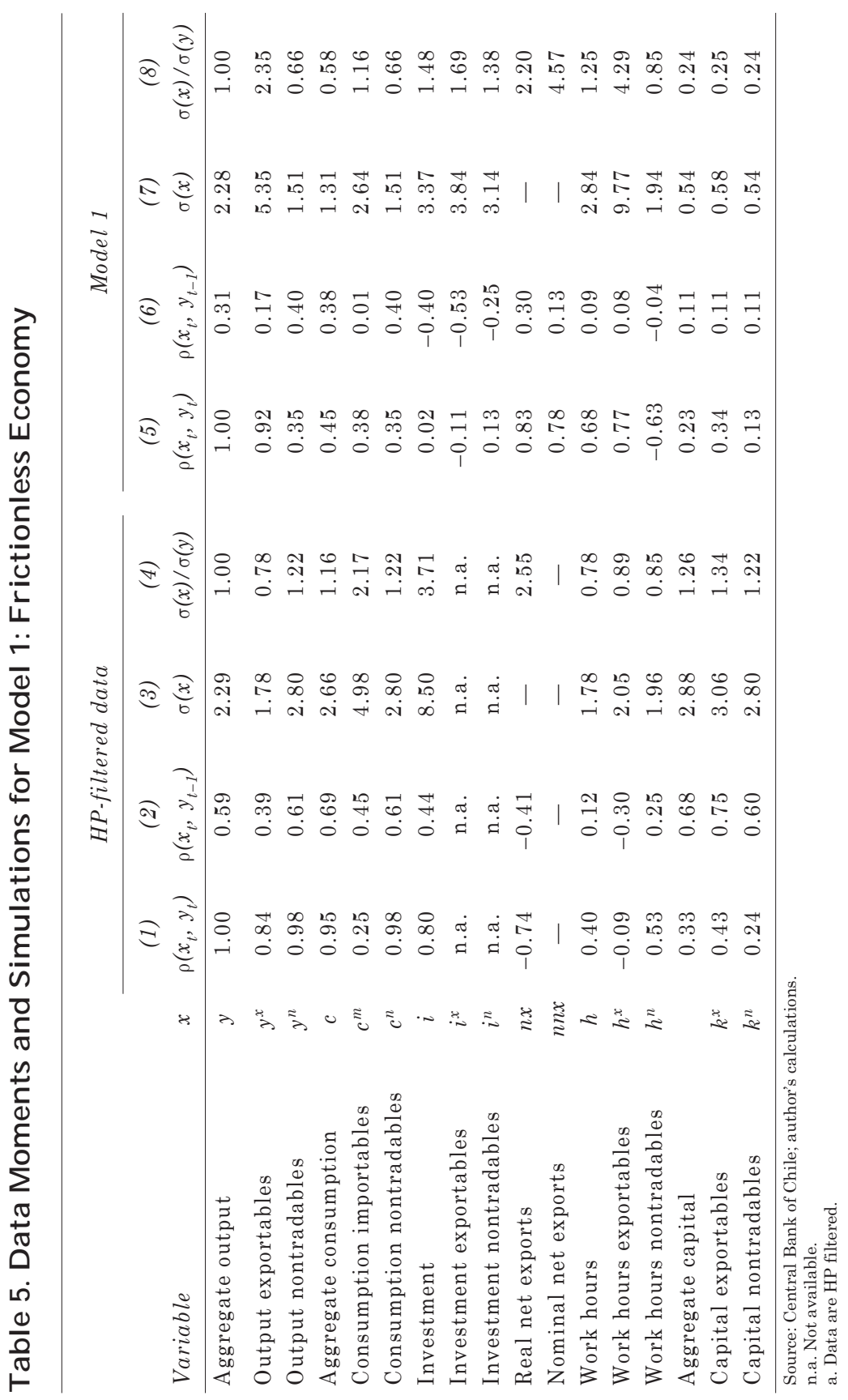




\section{Figure 2. Data and Model 1 Simulations}

Real GDP

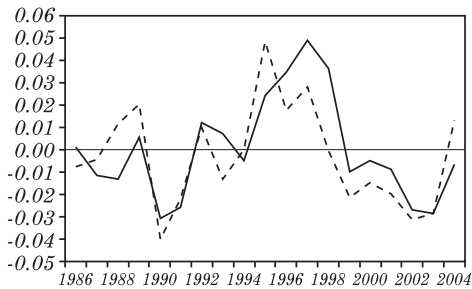

Aggregate investment

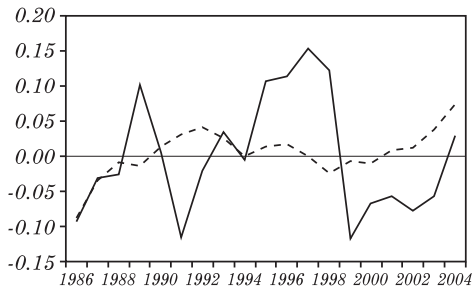

Real GDP exportables

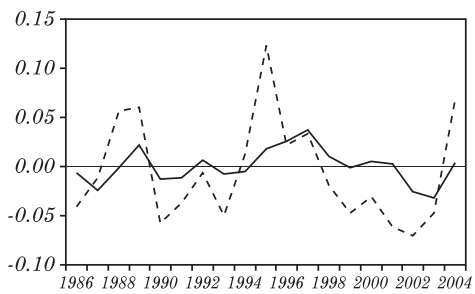

Consumption of importables

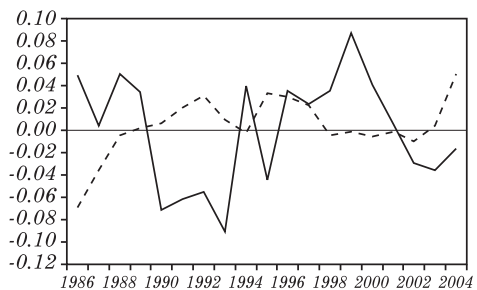

Aggregate consumption

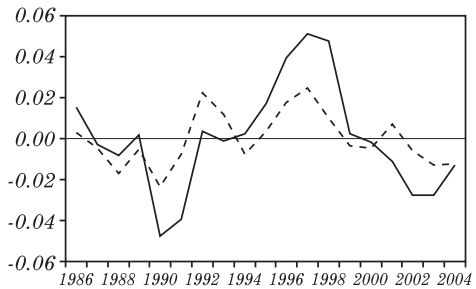

Real net exports

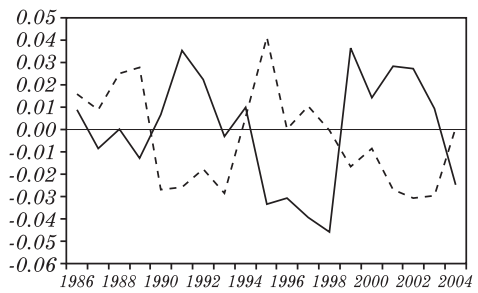

Real GDP and consumption of nontradables

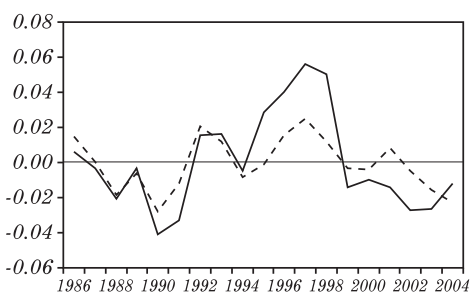

Total hours of work

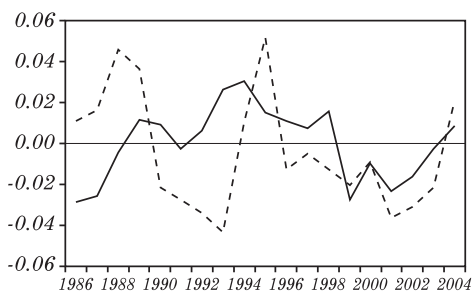




\section{Figure 2. (continued)}

Hours of work in exportables

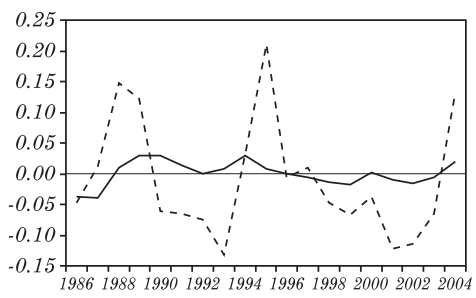

Investment in exportables

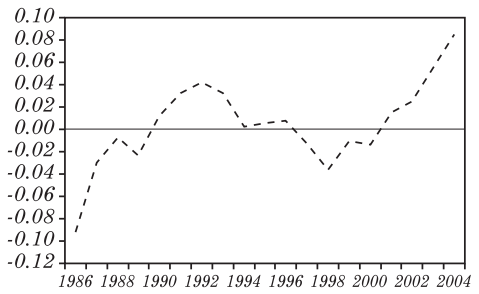

External debt

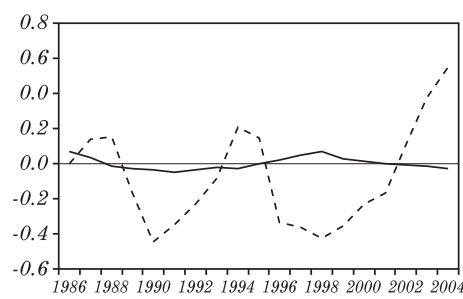

Capital stock of exportables

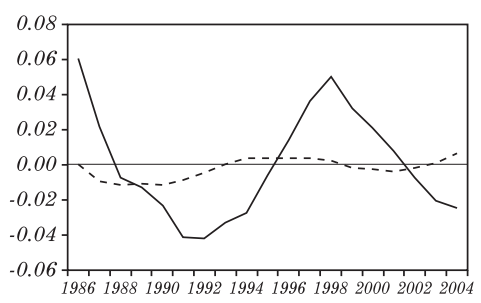

Hours of work in nontradables

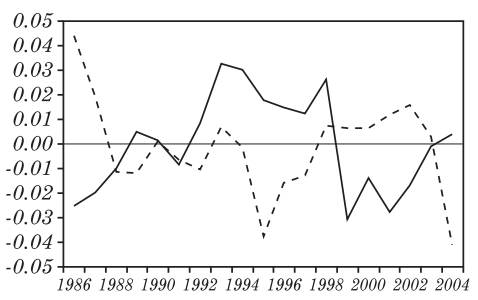

Investment in nontradables

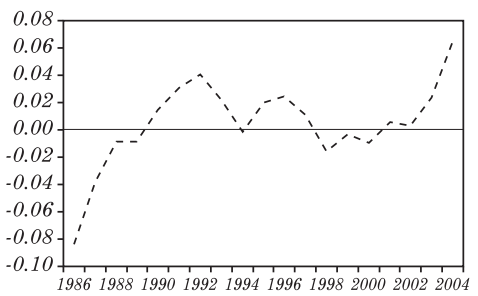

Aggregate capital stock

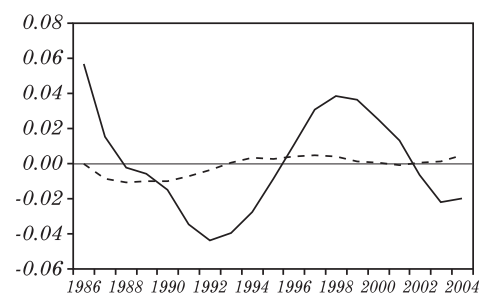

Capital stock of nontradables

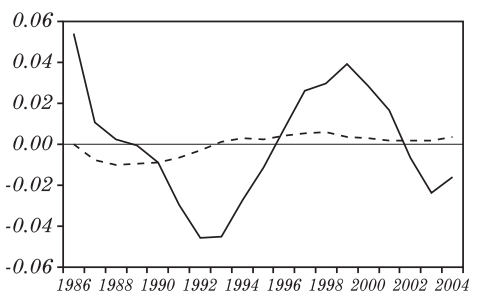

- Data - - - Model 1

Source: Central Bank of Chile; author's computations. 
Figure 2 presents the data series and model 1 simulations for the same sample. Model 1 predicts a smaller fall in aggregate and nontradables consumption in 1990-91 and 2001-03, and a lower expansion in 1994-98, resulting in the lower procyclicality and volatility relative to the data. For investment, the model also predicts a lower expansion in 1989 and in 1995-98, together with a smaller fall in 1991-92 and 1999-2004. Aggregate and export sector work hours move similarly to the terms of trade. Labor supply is highly procyclical and volatile. Together with the procyclical reallocations of labor from the nontradables to the export sector, this results in highly volatile and procyclical output and employment in the export sector and-when added to the smooth path of consumption and investment-procyclical, rather than countercyclical, real net exports.

Figure 3 presents the real exchange rate, defined as the price of exportable over nontradable goods, and the spread between the domestic and foreign interest rates in the data and in the different models. It shows that model 1 is unable to replicate the real depreciation between 1988 and 1992 and since 2002, as well as the decline in the foreign lending spread after 2000. Thus, a frictionless model with standard preferences and a normal intertemporal elasticity of substitution cannot generate the regularities observed in middle-income countries, as it predicts excessive consumption smoothing and procyclical real net exports. The next section explores whether adding an external borrowing constraint to this setup can solve these problems.

\section{Model 2: Borrowing-Constrained Economy}

Consider a small open economy that is perfectly integrated with the world in goods, but faces individual specific external borrowing constraints identified as the external lenders' requirement that domestic households finance at least a fraction $\Psi_{t}$ of their expenditures with their current income at date $t$ (Mendoza, 2001):

$$
w_{t} h_{t}+q_{t}^{X} k_{t}^{X}+q_{t}^{N} k_{t}^{N} \geq \Psi_{t}\left(c_{t}^{M}+P_{t}^{N} c_{t}^{N}+i_{t}^{X}+i_{t}^{N}-R_{t} b_{t}\right)
$$

where the left-hand side is the households' current income and the right-hand side the minimum fraction of expenditures to be selffinanced. When equations (27) and (8) are combined and equilibrium conditions imposed, this constraint can re-expressed as 


\section{Figure 3. Real Exchange Rates and Foreign Lending}

\section{Spreads $^{a}$}

A. Real Exchange Rate

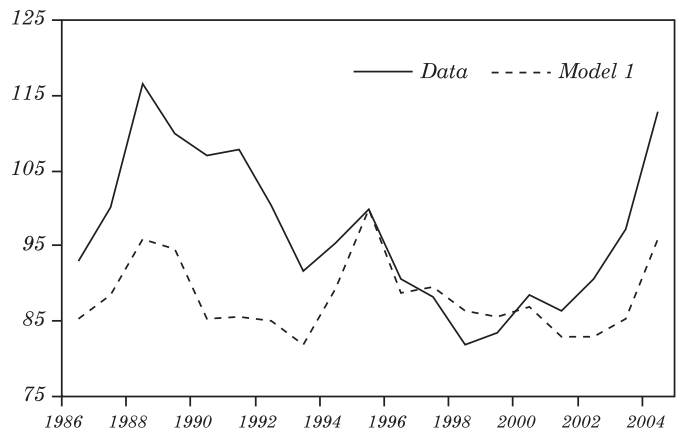

B. Foreign Lending Spread

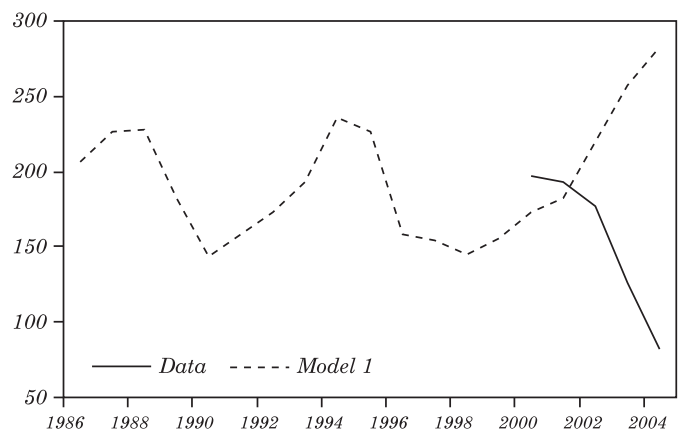

Source: J.P. Morgan's EMBI Global; author's computations.

a.Real exchange rate is measured as the ratio between the price of exportable goods and the price of nontradable goods. Foreign lending spread corresponds to the differential between the domestic interest rate and the foreign interest rate.

$b_{t+1} \geq-\frac{1-\Psi_{t}}{\gamma \Psi_{t}}\left(P_{t}^{X} Y_{t}^{X}+P_{t}^{N} Y_{t}^{N}\right)$

This constraint can replicate an optimal contract as in Atkeson (1991), in which foreign lending occurs under moral hazard and risk of repudiation. External lenders cannot observe whether borrowers are investing the loans efficiently or consuming them, and sovereign borrowers can repudiate their debt at any time. When there are no 
informational problems, domestic agents and external lenders share risk fully, but with these problems, the optimal contract reduces risk sharing, transferring part of the output risk to the domestic borrowers to induce them to invest efficiently and repay their loans. Furthermore, the external borrowing constraint should always bind to avoid saving accumulation and debt repudiation.

In this setup, full risk sharing is equivalent to a sufficiently procyclical $\Psi_{t}$, which allows domestic agents to borrow more relative to income in bad times than in good, smoothing expenditures over time. Less risk sharing is consistent with a less procyclical $\Psi_{t}$ and less expenditure smoothing. I assume that the constraint always binds and deduce $\Psi_{t}$ at each date $t$ to allow the model to replicate the real net exports in the data as a proxy for the household's net repayment to the foreign lenders. ${ }^{4}$ Then, $\Psi_{t}$ and the borrowing constraint multiplier are analyzed according to previous studies.

The rest of the model is the same. There are three types of agents: domestic households, domestic firms, and foreign lenders. Foreign lenders set the borrowing constraint on the domestic households. Domestic households own firms, consume the nontradable good, buy the importable good for consumption and investment, and supply labor and capital to the firms. There are two firms-the export firm and the nontradable firm - that demand capital and labor to produce their goods. The economy follows a balanced growth path, and population is assumed to be constant. In the following subsections, the model is set in stationary form.

\subsection{Households}

Households choose the sequence $\left.\left\{c_{t}^{M}, c_{t}^{N}, l_{t}, i_{t}, k_{t+1}, b_{t+1}\right\}\right|_{t=0} ^{\infty}$ to maximize their lifetime utility (equation 6), subject to equations (8), (9), and (27). Their first-order conditions are as follows:

$$
\begin{aligned}
& \alpha \varpi\left[\varpi c_{t}^{M_{\rho}}+(1-\varpi) c_{t}^{N_{\rho}}\right]^{\frac{\alpha}{\sigma}(1-\sigma)-1}\left(1-h_{t}\right)^{(1-\alpha)(1-\sigma)} c_{t}^{M(\rho-1)}=\left(\lambda_{t}+\mu_{t} \Psi_{t}\right) ; \\
& \begin{array}{r}
\alpha(1-\varpi)\left[\varpi c_{t}^{M_{\rho}}+(1-\varpi) c_{t}^{N_{\rho}}\right]^{\frac{\alpha}{\rho}(1-\sigma)-1}\left(1-h_{t}\right)^{(1-\alpha)(1-\sigma)} c_{t}^{N(\rho-1)} \\
=P_{t}^{N}\left(\lambda_{t}+\mu_{t} \Psi_{t}\right) ;
\end{array}
\end{aligned}
$$

4. This avoids private agents building up savings that would make the constraint nonbinding again. 


$$
\begin{aligned}
& (1-\alpha)\left[\varpi c_{t}^{M_{\rho}}+(1-\varpi) c_{t}^{N \rho}\right]^{\frac{\alpha}{\rho}(1-\sigma)}\left(1-h_{t}\right)^{\alpha(\sigma-1)-\sigma}=\left(\lambda_{t}+\mu_{t}\right) w_{t} ; \\
& \phi_{t}^{X}=\left(\lambda_{t}+\mu_{t} \Psi_{t}\right)+\phi_{t}^{X} \theta i_{t}^{X} ; \\
& \phi_{t}^{N}=\left(\lambda_{t}+\mu_{t} \Psi_{t}\right)+\phi_{t}^{N} \theta i_{t}^{N} ; \\
& \gamma \phi_{t}^{X}=\beta E_{t}\left[\left(\lambda_{t+1}+\mu_{t+1}\right) q_{t+1}^{X}+\phi_{t+1}^{X}(1-\delta)\right] ; \\
& \gamma \phi_{t}^{N}=\beta E_{t}\left[\left(\lambda_{t+1}+\mu_{t+1}\right) q_{t+1}^{N}+\phi_{t+1}^{N}(1-\delta)\right] ; \\
& \gamma \lambda_{t}=\beta E_{t}\left[\left(\lambda_{t+1}+\mu_{t+1} \Psi_{t+1}\right) R_{t+1}\right] ; \text { and } \\
& E_{t}\left[\lim _{t \rightarrow \infty} \beta^{t} \lambda_{t}\left(k_{t+1}^{X}+k_{t+1}^{N}+b_{t+1}\right)\right]=0 ;
\end{aligned}
$$

where $\lambda_{t}, \varphi_{t}^{X}, \varphi_{t}^{N}$, and $\mu_{t}$ are the Lagrange multipliers on equations (8), (9), and (27), respectively.

\subsection{Firms}

Firms solve the problem in model 1. Thus, their first-order conditions are equations (19) and (20) for the nontradable firm and equations (21) and (22) for the export firm.

\subsection{Competitive Equilibrium}

Given $b_{0}, k_{0}^{X}$, and $k_{0}^{N}$ and shocks' processes $\left(\varepsilon_{t}^{R}, \varepsilon_{t}^{P_{X}}, \varepsilon_{t}^{X}, \varepsilon_{t}^{N}, \Psi_{t}\right)$, a competitive equilibrium corresponds to sequences of allocations $\left\{c_{t}^{M}\right.$, $\left.c_{t}^{N}, h_{t}, i_{t}^{X}, i_{t}^{N}, k_{t+1}^{X}, k_{t+1}^{N}, b_{t+1}\right\}\left.\right|_{t=0} ^{\infty},\left.\left\{h_{t}^{f X}, h_{t}^{f N}, k_{t}^{f X}, k_{t}^{f N}\right\}\right|_{t=0} ^{\infty}$ and prices $\left\{P_{t}^{X}\right.$, $\left.P_{t}^{N}, q_{t}^{X}, q_{t}^{N}, w_{t}, R_{t}\right\}\left.\right|_{t=0} ^{\infty}$ such that:

-Given $b_{0}, k_{0}^{X}, k_{0}^{N}$, prices, and shocks' processes, $\left\{c_{t}^{M}, c_{t}^{N}, h_{t}, i_{t}^{X}\right.$, $\left.i_{t}^{N}, k_{t+1}^{X}, k_{t+1}^{N}, b_{t+1}\right\}\left.\right|_{t=0} ^{\infty}$ solve the households' problem; 
—Given prices and shocks' processes, $\left\{h_{t}^{f X}, k_{t}^{f X}\right\}_{t=0}^{\infty}$ solve firm X's problem;

-Given prices and shocks' processes, $\left.\left\{h_{t}^{f N}, k_{t}^{f N}\right\}\right|_{t=0} ^{\infty}$ solve firm N's problem;

-Market-clearing conditions are satisfied: $c_{t}^{N}=y_{t}^{N}, k_{t}^{X}=k_{t}^{f X}$, $k_{t}^{N}=k_{t}^{f N}$, and $h_{t}=h_{t}^{f X}+h_{t}^{f N}$; and

-The resource constraint is satisfied:

$R_{t} b_{t}+P_{t}^{X} Y_{t}^{X}-c_{t}^{M}-i_{t}^{X}-i_{t}^{N}-\gamma b_{t+1}=0$.

\subsection{External Lenders}

External lenders are risk neutral and face a complete asset market. They maximize the profit function (38) subject to the domestic households' borrowing constraint (equation 27):

$\Pi^{*}=E_{0}\left\{\sum_{t=0}^{\infty} Q_{t} \gamma^{t}\left[R_{t} b_{t}-(1+\Phi) \gamma b_{t+1}\right]\right\}$,

with $Q_{t}=\left(\prod_{s=0}^{t} R_{s}^{*}\right)^{-1}$, where $\Phi$ is the marginal cost of extending new loans. Their first-order conditions are:

$Q_{t}(1+\Phi)=Q_{t+1} R_{t+1}\left(1-\mu_{t+1} \Psi_{t+1}\right)$,

which yields the following endogenous upward-sloping supply of funds:

$R_{t}-R_{t}^{*}=R_{t}^{*} \Phi+R_{t} \mu_{t} \Psi_{t}$.

This supply of funds depends not only on net foreign assets as in model 1, but also on current expenditures and income, all of which are reflected in the multiplier, $\mu_{t}$. As before, this functional form allows the model to have a unique steady state. 


\subsection{Steady State and Calibration}

The calibrated parameters and the implied macroeconomic ratios from the model are the same as in model 1 , as $\mu$ is small. The only difference is that the parameters associated with the previous upward supply of funds ( $\eta$ and $\bar{b}$ in equation 1 ) are now replaced by the coefficients associated with the endogenous upward supply of funds $(\Phi, \Psi$, and $\mu$ in equation 40 ), which are presented in table 3.

\subsection{Simulations}

The value of $\Psi_{t}$ is deduced and introduced as a shock, together with the shocks in model 1 , to make model 2 replicate Chile's real net exports between 1986 and 2004. Table 6, shows that $\Psi_{t}$ is highly persistent and more volatile than output. Its innovations are positively correlated with all shocks, but this correlation is higher with the terms of trade than with productivity, which is consistent with a high (low) risk sharing between households and foreign lenders when shocks are observable (unobservable). Figure 1, panel B, shows that $\Psi_{t}$ was increasing in 1986-95, decreasing in 1996-98, stable until 2003, and increasing again in 2004 . The multiplier, $\mu_{t}$, shows a more binding constraint in 1990-91 and after 1998, when facing negative shocks to productivity and the terms of trade, and a less binding constraint when facing positive shocks (1992-98). This indicates that this constraint may have contributed to the boom in 1995-98 and to the bust in 1999-2003.

Table 7 shows that model 2 captures the volatilities of exportable and nontradable output, consumption of importable goods, and aggregate investment better than model 1 . It also reduces the volatility of export sector's work hours, but increases that of the aggregate and nontradables sector's hours. Figure 4 shows that model 2 reproduces investment, consumption of importable goods, and output of exportable goods better than model 1. Investment is more procyclical and more volatile since $\Psi_{t}$ is highly persistent and highly correlated to the terms of trade. The less binding constraint in 1992-98 produced larger and longer-lasting increases in investment, while the tighter constraint in 1999-2003 produced larger and longer-lasting reductions in investment. 


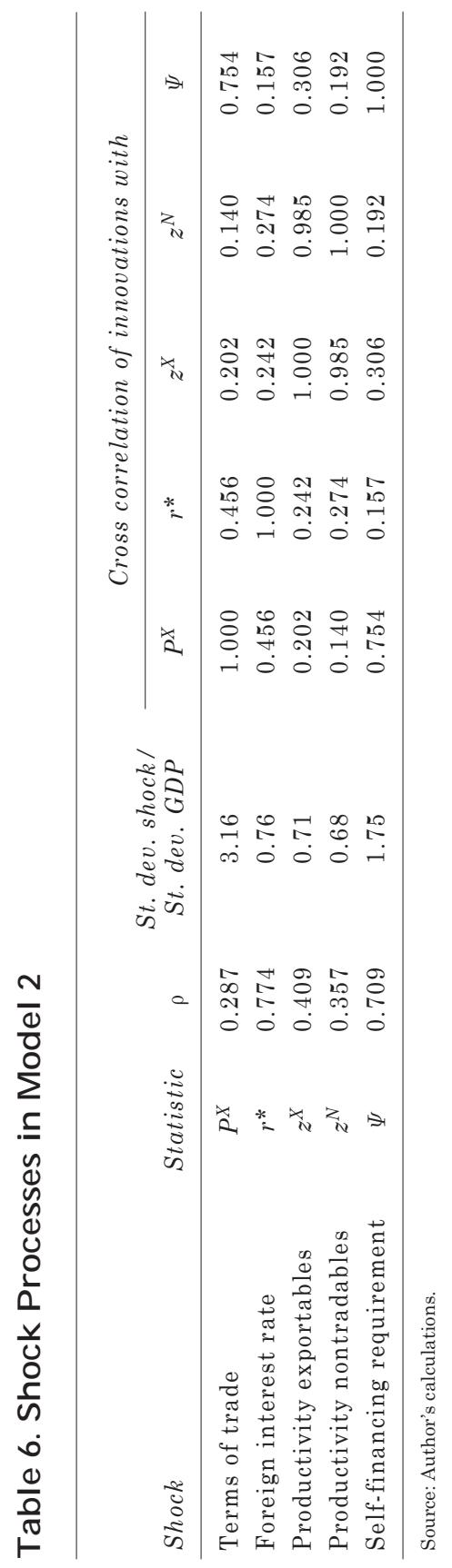




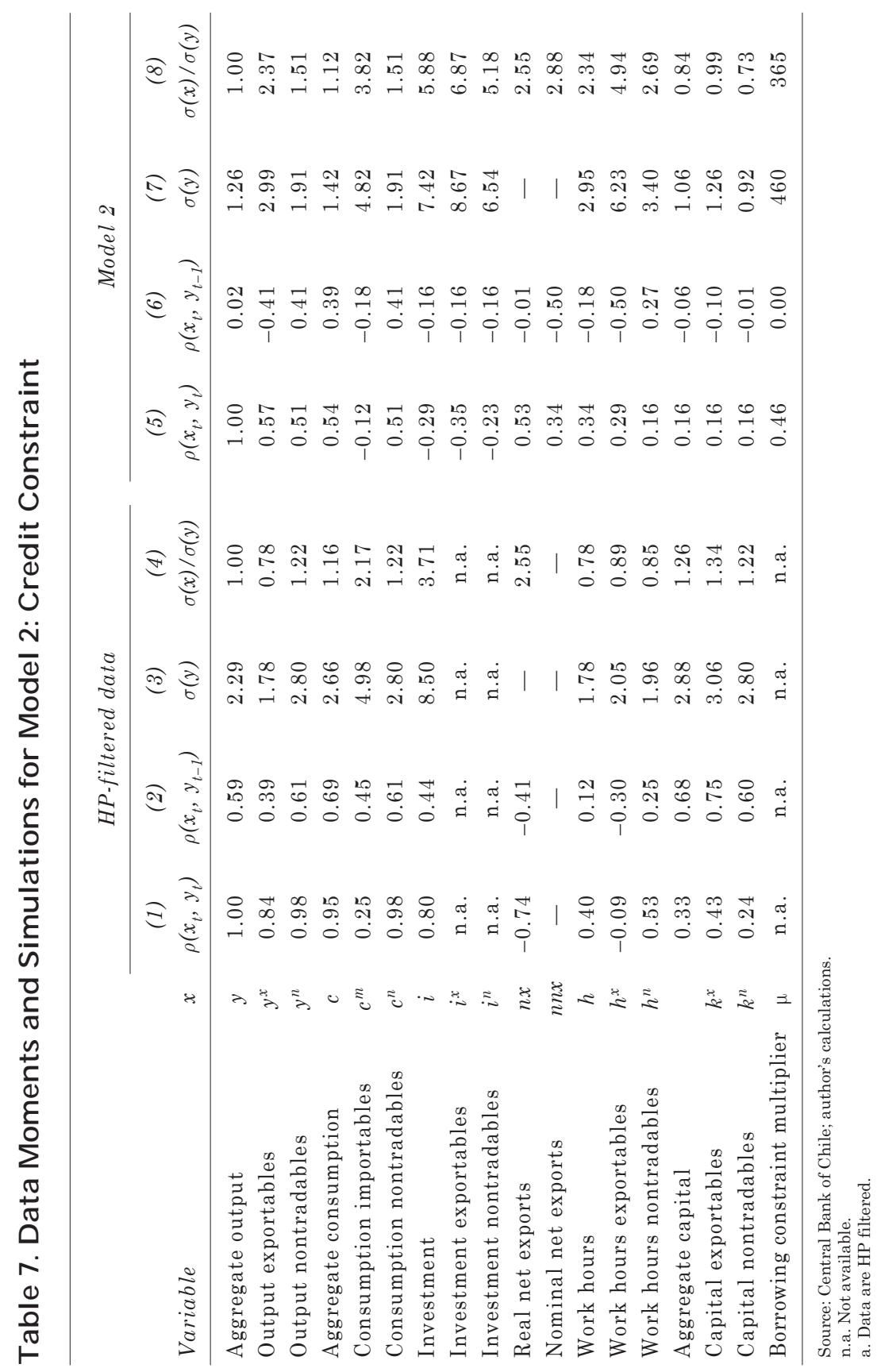


Figure 4. Data and Model 1 and Model 2 Simulations

Real GDP

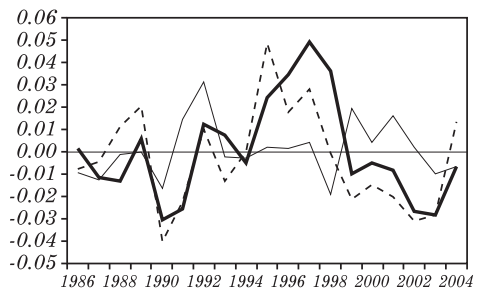

Aggregate investment

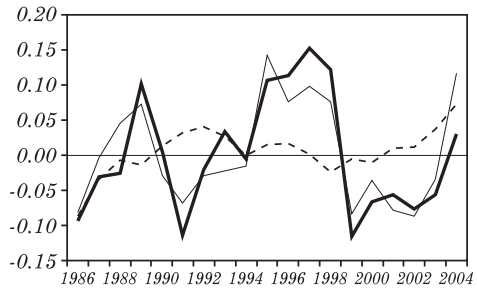

Real GDP exportables

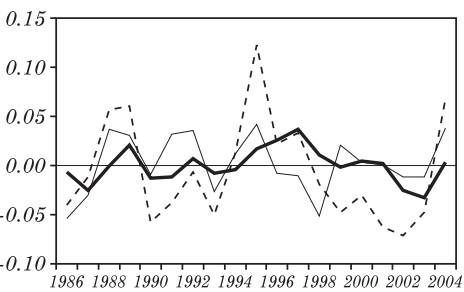

Consumption of importables

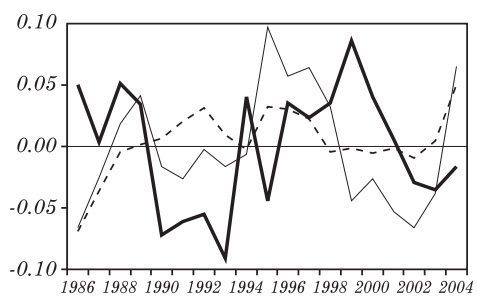

Aggregate consumption

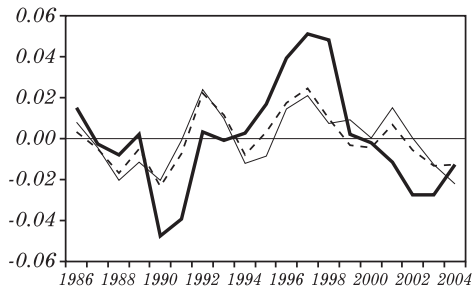

Real net exports

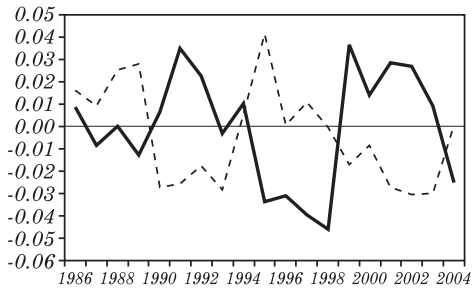

Real GDP and consumption of nontradables

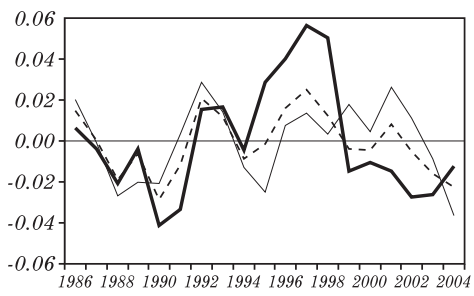

Total hours of work

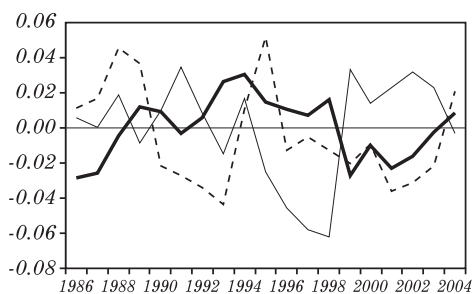


Figure 4. (continued)

Hours of work in exportables

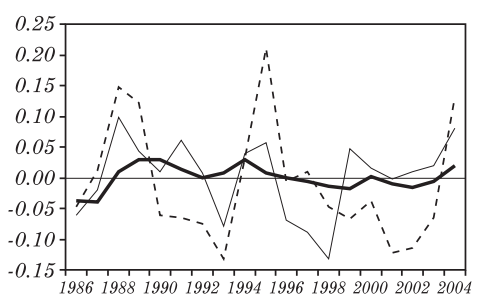

Investment in exportables

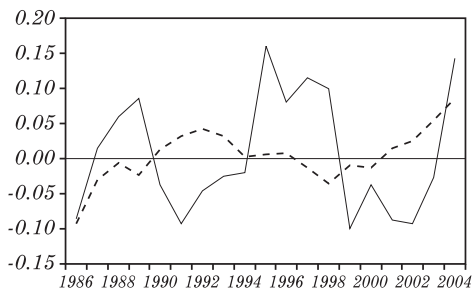

External debt

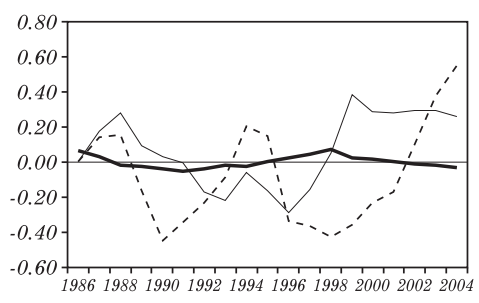

Capital stock of exportables

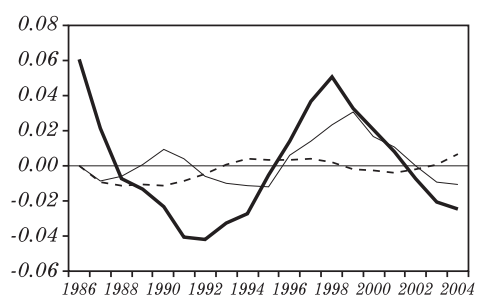

Hours of work in nontradables

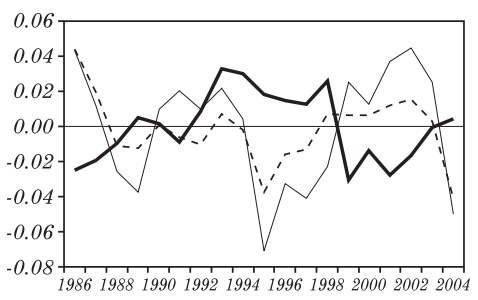

Investment in nontradables

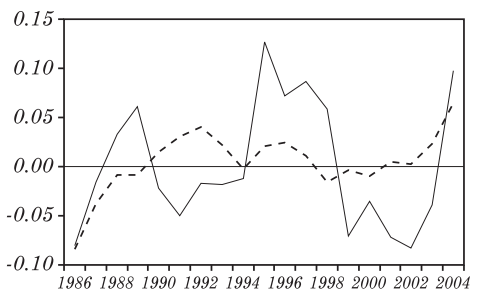

Aggregate capital stock

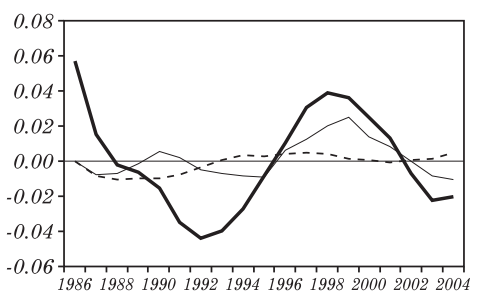

Capital stock of nontradables

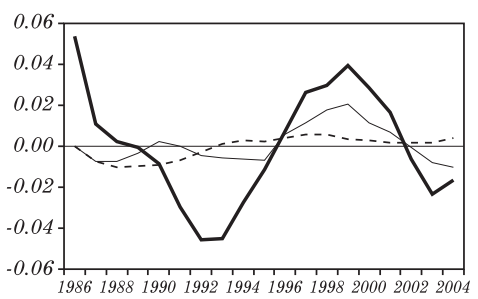

Data ---Model $1-$ Model 2

Source: Central Bank of Chile; author's computations. 
FigHouseholds react to positive shocks and a less binding constraint by increasing consumption and reducing their labor effort. The importable goods are obtained abroad, while nontradables are produced domestically, generating a reallocation of labor from the exportable to the nontradables sector. The lower overall labor effort further reduces employment in the export sector and lowers the increase in employment in the nontradables sector. Thus, the demand for tradable goods increases, but their production falls, generating countercyclical real net exports. Figure 5 shows that model 2 replicates the real exchange rate better than model 1 , and it predicts a flat foreign lending spread, as $\mu \mathrm{t}$ is small.

\section{Figure 5. Real Exchange Rate and Foreign Lending Spread ${ }^{\mathrm{a}}$}

A. Real Exchange Rate

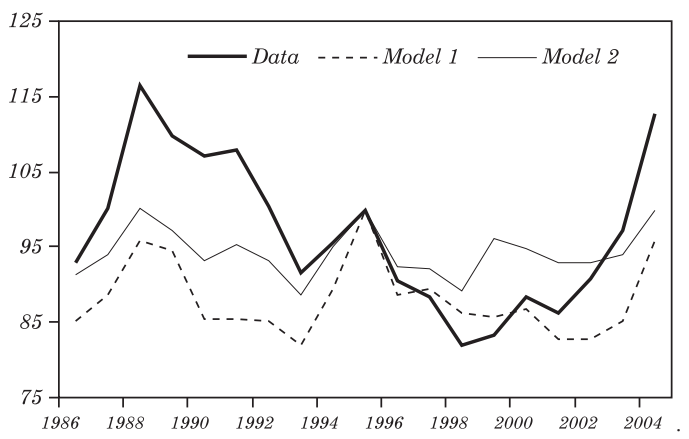

B. Foreign Lending Spread

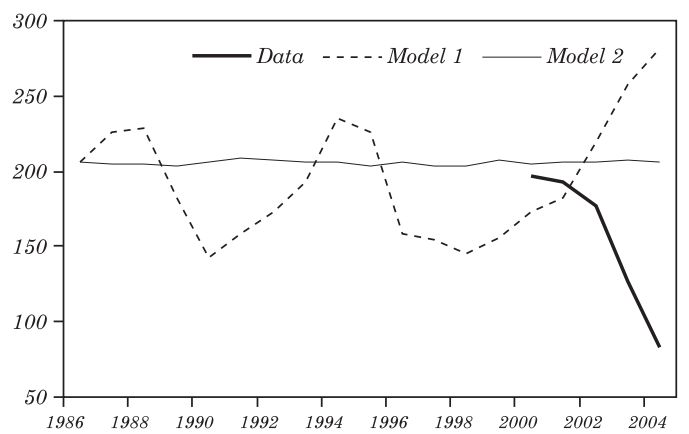

Source: J.P. Morgan's EMBI Global; author's computations.

a.Real exchange rate is measured as the ratio between the price of exportable goods and the price of nontradable goods. Foreign lending spread corresponds to the differential between the domestic interest rate and the foreign interest rate. 
Work hours, however, are countercyclical instead of procyclical, and the volatility of nontradables consumption is still low compared to the data. In figure 4, work hours are higher in periods of negative shocks and a tighter constraint (1990-91 and 1999-2003) than in periods of positive shocks and a less binding constraint (1992-98). Since the countercyclical fluctuations in labor supply drive the cyclical path of work hours, the next section explores whether countercyclical laborfinancing wedges can produce sufficiently procyclical fluctuations in the labor demand to solve this problem.

\section{Model 3: Asymmetric Financing Costs}

Consider a small economy that is perfectly open to the world in goods, but faces the same upward-sloping supply of external funds as in model 1 (equation 1). Domestic households own firms, consume the $N$ good, buy the $M$ good for consumption and investment, and supply $h$ and $k$ to the firms. The export and nontradable firms demand $k$ and $h$ to produce their goods. They face a specific labor-financing wedge that can capture sector-specific labor market distortions such as labor-financing frictions, sticky wages, or unions (Chari, Kehoe, and McGrattan, 2003) or labor market regulations (Caballero and others, 2004).

The appendix shows that this model is similar to a model in which firms need to borrow from domestic banks to pay workers in advance of production, such that they face a credit-in-advance constraint. The cost of credit depends on each firm's specific availability of collateral. This is motivated by the evidence found by Tornell and Westermann $(2002,2003)$ about asymmetric financing opportunities across tradable and nontradable firms for a sample of middle-income countries, and by Caballero (2002) for Chile. Given the lack of data on sectoral financing costs, I deduced the sectoral labor-financing wedge to make the model replicate output of both sectors in the data between 1986 and 2004. The economy follows a balanced growth path, and population is constant. In the following discussion, the model is set in stationary form.

\subsection{Households}

Households solve the same problem as in the friction-less economy setup. Their first-order conditions are thus given by equations (10)-(18). 


\subsection{Firms}

Each firm's labor-financing wedge is set as augmenting the cost of labor by a fraction, $\tau_{t}^{j}$, with $j=X, N$. Their total cost of production is given by equation (41):

$$
q_{t}^{j} k_{t}^{f j}+w_{t} h_{t}^{f j}\left(1+\tau_{t}^{j}\right)
$$

for $j=X, N$. The costs associated with the wedges are rebated to the households as a lump sum transfer, such that the resource constraint remains unchanged with respect to the previous specifications. The firms' static problem is to choose the allocation $\left\{h_{t}^{f j}, k_{t}^{f j}\right\}$ to maximize profits. The first-order conditions for the nontradable firm are

$$
\begin{aligned}
& w_{t}\left(1+\tau_{t}^{N}\right)=\left(1-\alpha_{N}\right) P_{t}^{N} \exp \left(\varepsilon_{t}^{N}\right)\left(k_{t}^{f N}\right)^{\alpha_{N}}\left(h_{t}^{f N}\right)^{-\alpha_{N}} \text { and } \\
& q_{t}^{N}=\alpha_{N} P_{t}^{N} \exp \left(\varepsilon_{t}^{N}\right)\left(h_{t}^{f N}\right)^{\left(1-\alpha_{N}\right)}\left(k_{t}^{f N}\right)^{\left(\alpha_{N}-1\right)} ;
\end{aligned}
$$

while for the export firm, they are

$$
\begin{aligned}
& w_{t}\left(1+\tau_{t}^{X}\right)=\left(1-\alpha_{X}\right) P_{t}^{X} \exp \left(\varepsilon_{t}^{X}\right)\left(k_{t}^{f X}\right)^{\alpha_{X}}\left(h_{t}^{f X}\right)^{-\alpha_{X}} \text { and } \\
& q_{t}^{X}=\alpha_{X} P_{t}^{X} \exp \left(\varepsilon_{t}^{X}\right)\left(h_{t}^{f X}\right)^{\left(1-\alpha_{X}\right)}\left(k_{t}^{f X}\right)^{\left(\alpha_{X}-1\right)} .
\end{aligned}
$$

\subsection{Competitive Equilibrium}

Given $b_{0}, k_{0}^{X}$, and $k_{0}^{N}$ and shocks' processes $\left(\varepsilon_{t}^{R}, \varepsilon_{t}^{P_{X}}, \varepsilon_{t}^{X}, \varepsilon_{t}^{N}, \tau_{t}^{X}, \tau_{t}^{N}\right)$, a competitive equilibrium corresponds to sequences of allocations $\left\{c_{t}^{M}\right.$, $\left.c_{t}^{N}, h_{t}, i_{t}^{X}, i_{t}^{N}, k_{t+1}^{X}, k_{t+1}^{N}, b_{t+1}\right\}\left.\right|_{t=0} ^{\infty},\left.\left\{h_{t}^{f X}, h_{t}^{f N}, k_{t}^{f X}, k_{t}^{f N}\right\}\right|_{t=0} ^{\infty}$ and prices $\left\{P_{t}^{X}\right.$, $\left.P_{t}^{N}, q_{t}^{X}, q_{t}^{N}, w_{t}, R_{t}\right\}\left.\right|_{t=0} ^{\infty}$ such that:

-Given $b_{0}, k_{0}^{X}, k_{0}^{N}$, prices, and shocks' processes, $\left\{c_{t}^{M}, c_{t}^{N}, h_{t}, i_{t}^{X}\right.$, $\left.i_{t}^{N}, k_{t+1}^{X}, k_{t+1}^{N}, b_{t+1}\right\}\left.\right|_{t=0} ^{\infty}$ solve the households' problem; 
-Given prices and shocks' processes, $\left.\left\{h_{t}^{f X}, k_{t}^{f X}\right\}\right|_{t=0} ^{\infty}$ solve firm X's problem;

—Given prices and shocks' processes, $\left.\left\{h_{t}^{f N}, k_{t}^{f N}\right\}\right|_{t=0} ^{\infty}$ solve firm N's problem;

- Market-clearing conditions are satisfied: $c_{t}^{N}=y_{t}^{N}, k_{t}^{X}=k_{t}^{f X}$, $k_{t}^{N}=k_{t}^{f N}$, and $h_{t}=h_{t}^{f X}+h_{t}^{f N}$; and

-The resource constraint is satisfied:

$R_{t} b_{t}+P_{t}^{X} Y_{t}^{X}-c_{t}^{M}-i_{t}^{X}-i_{t}^{N}-\gamma b_{t+1}=0$.

\subsection{Steady State and Calibration}

Both wedges, $\tau_{t}^{X}$ and $\tau_{t}^{N}$, in table 3 are set to ensure that they are always greater than or equal to zero in the simulations. The nontradable wedge is about one percentage point above the export wedge. This specification only marginally changes the relative allocation of labor across sectors in steady state, while the other parameters and macroeconomic ratios remain as in models 1 and 2 .

\subsection{Simulations}

Both wedges are deduced and introduced as shocks to make the model replicate the path of output of exportable and nontradable goods in the data. The model is simulated for these shocks and for the four shocks in model 1 . Table 8 shows that the nontradable wedge is more persistent and less volatile than the export wedge. Its innovations are negatively correlated with both productivity shocks and uncorrelated with the terms of trade, while the innovations to the export wedge are highly correlated with the terms of trade and less correlated with productivity.

Figure 1, panel C, shows that the nontradable wedge decreased continuously between 1991 and 1998 and increased suddenly in 1999 . It then remained high until 2004, mirroring the path of nontradable output, consistent with a lower cost of domestic credit during booms than during recessions. The export wedge mimics the path of the terms of trade in the data, probably reducing the reallocation of labor across sectors rather than measuring changes in domestic financing costs.

Table 9 presents the simulated moments for model 3, which replicates the output moments in both sectors in the data by 


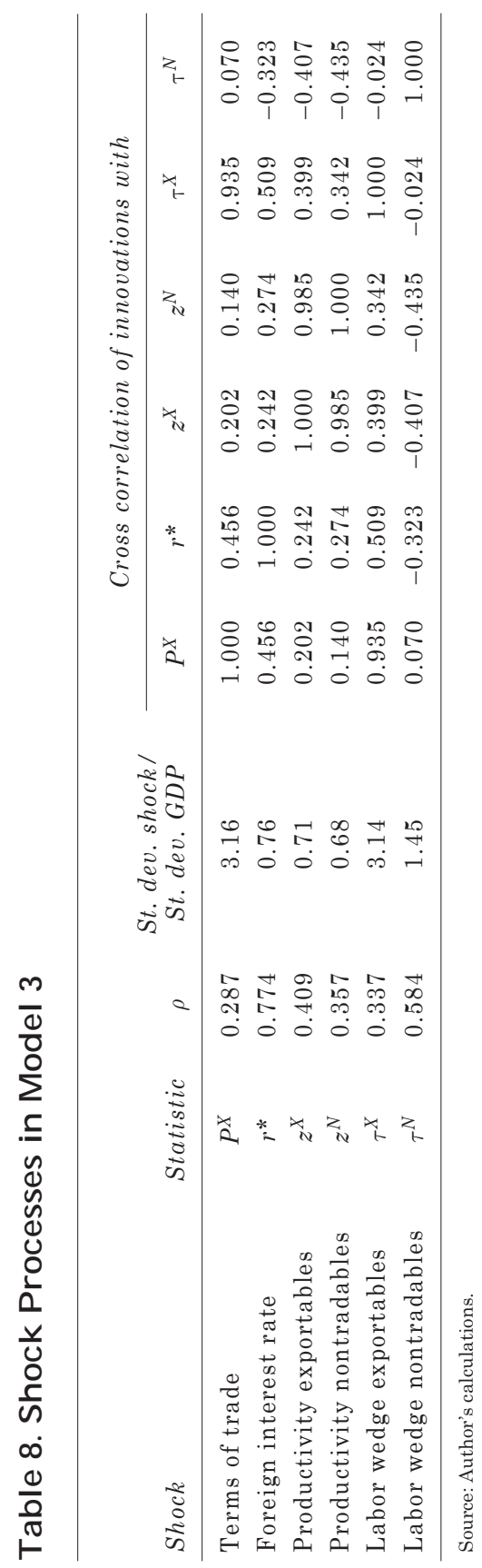




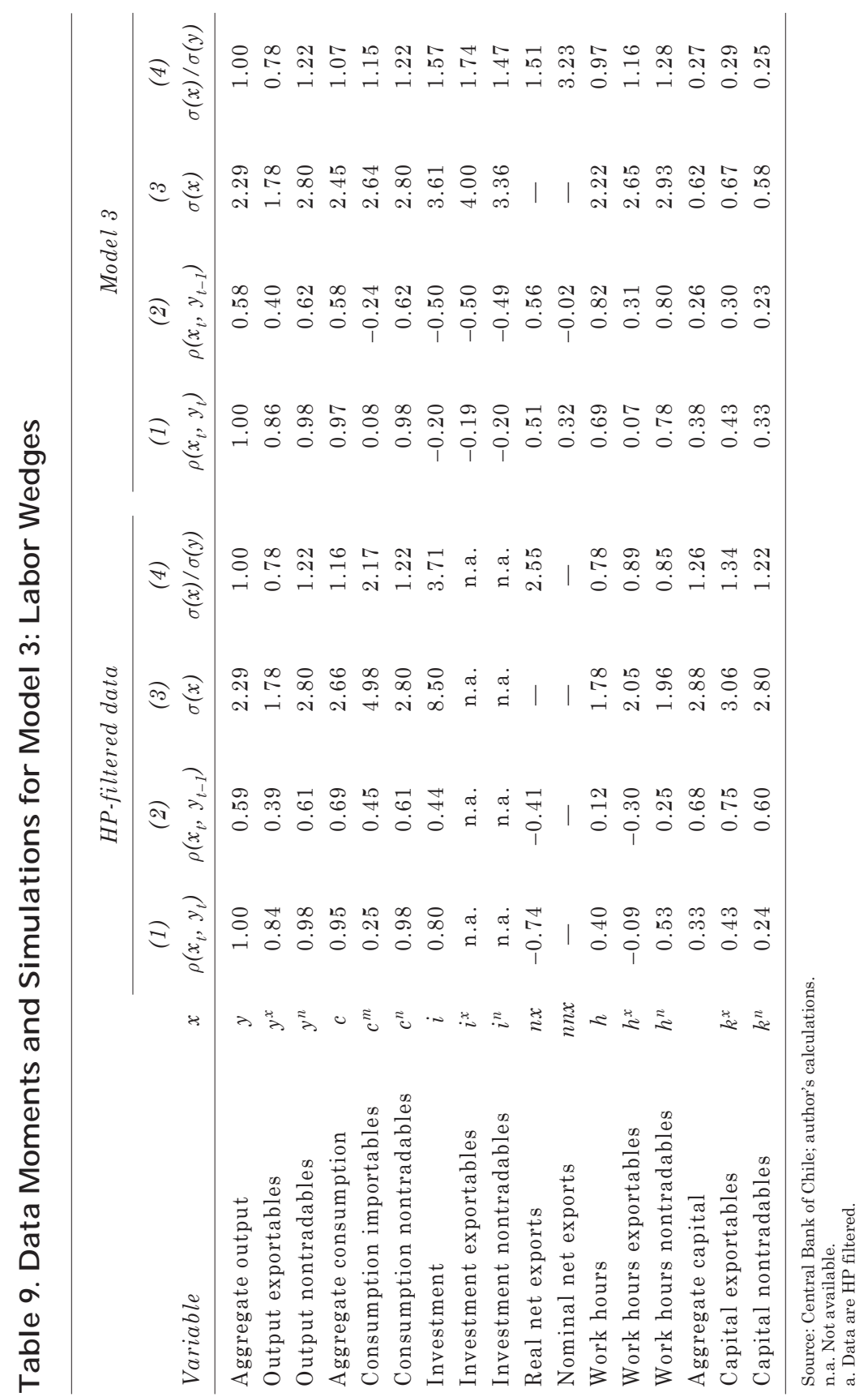


construction. Relative to model 2 , model 3 better reproduces the volatility and procyclicality of consumption and total and sectoral work hours, but not the procyclicality and volatility of investment and consumption of importable goods or the countercyclicality of real net exports. Figure 6 shows that model 3 better replicates aggregate consumption, as it replicates the nontradable part by construction. Also, since the wedges generate a procyclical labor demand, it better replicates total and nontradable work hours, in particular their increase between 1994 and 1998 and their fall between 1999 and 2003. It does not, however, capture the path of hours in the export sector.

Figure 7 shows that model 3 does not replicate the real exchange rate or the foreign lending spread. The main drawback, however, is that real net exports are procyclical instead of countercyclical, since investment and consumption of importable goods are not sufficiently procyclical and volatile. Thus, the two frictions complement each other: the external borrowing constraint creates countercyclical real net exports, while the labor-financing wedge creates a procyclical and volatile nontradables consumption and employment. The next section considers the two frictions together.

\section{Model 4: External Borrowing Constraint and Asymmetric Financing Costs}

Consider a small open economy that is perfectly integrated with the world in goods, but has limited access to the external capital market. Foreign lenders set individual borrowing constraints on domestic households according to equation (27). Households own firms, consume the $N$ good, buy the $M$ good for consumption and investment, and supply $h$ and $k$ to the firms. The export and nontradable firms demand $k$ and $h$ to produce their goods. They face a specific labor-financing wedge that captures different sources of labor market distortions.

As in models 2 and 3, the self-financing requirement and the laborfinancing wedge are deduced to make the model replicate the paths of real net exports and of export and nontradable output in the data, respectively. Their moments and the moments of the other variables are then compared to those of models 2 and 3. The economy follows a balanced growth path, and population is constant. In the following discussion, the model is set in stationary form. 
Figure 6. Data and Model 1 and Model 3 Simulations

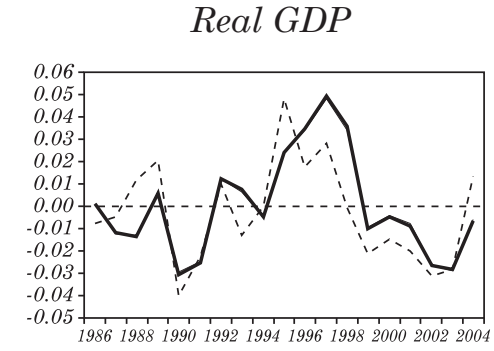

Aggregate investment

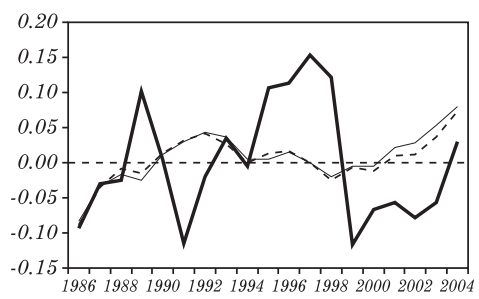

Real GDP exportables

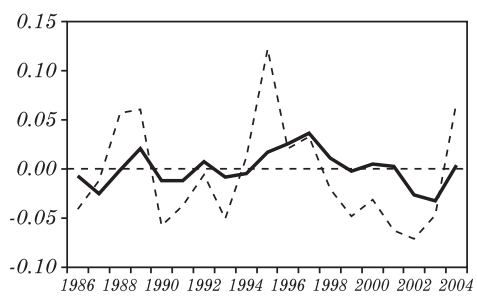

Consumption of importables

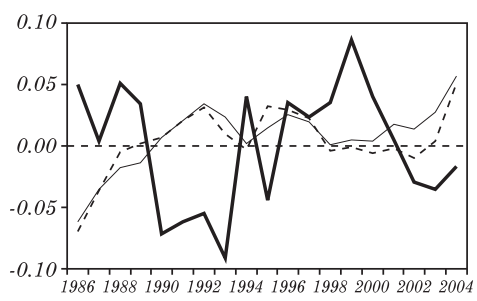

Aggregate consumption

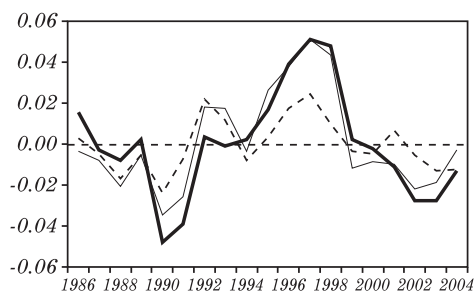

Real net exports

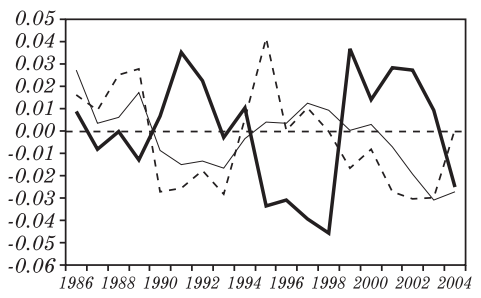

Real GDP and consumption of nontradables

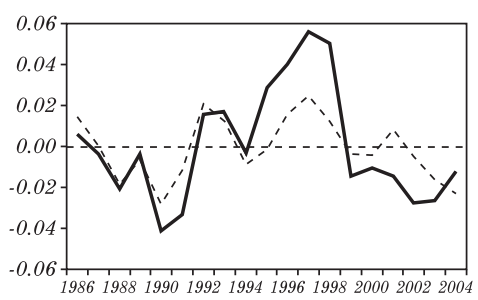

Total hours of work

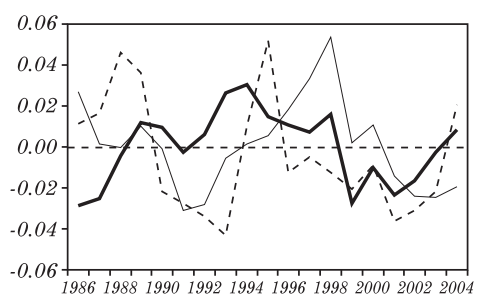




\section{Figure 6. (continued)}

Hours of work in exportables

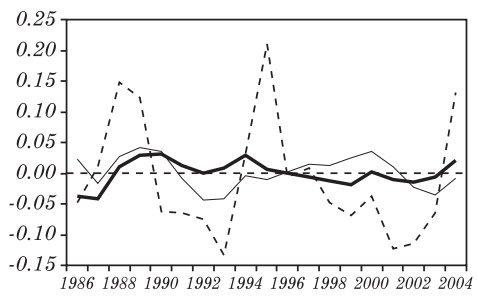

Investment in exportables

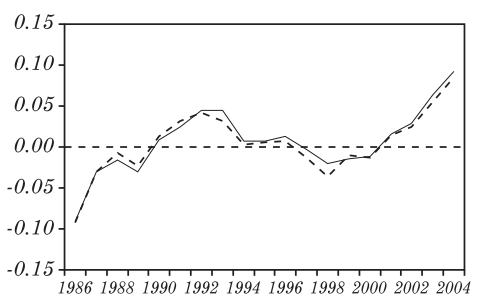

External debt

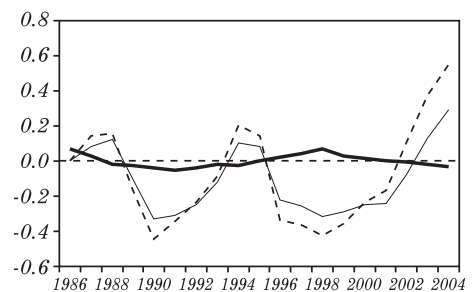

Capital stock

of exportables

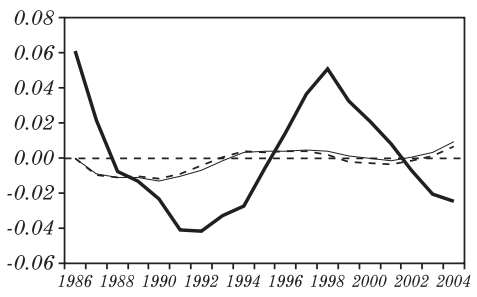

Hours of work in nontradables

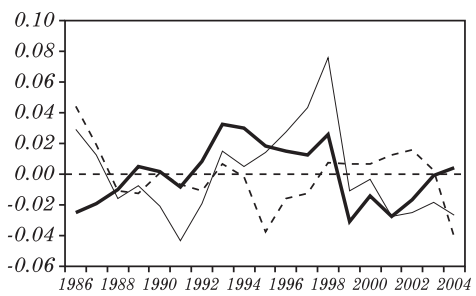

Investment in nontradables

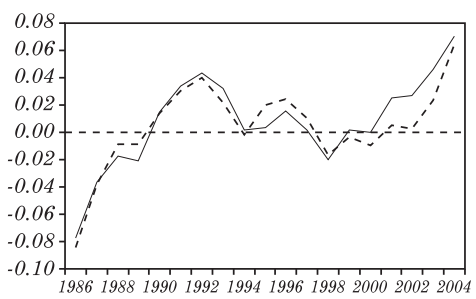

Aggregate capital stock

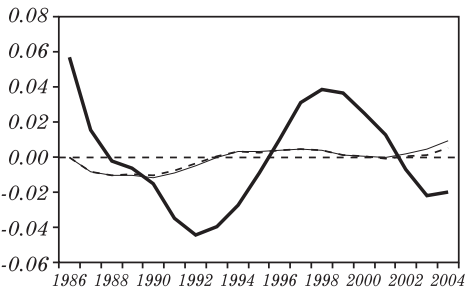

Capital stock

of nontradables

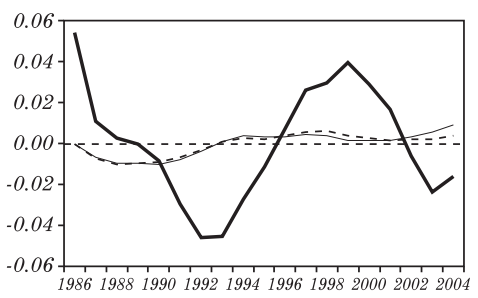

$\longrightarrow$ Data --- Model $1 \longrightarrow$ Model 3 
Figure 7. Real Exchange Rate and Foreign Lending Spread ${ }^{a}$

A. Real Exchange Rate

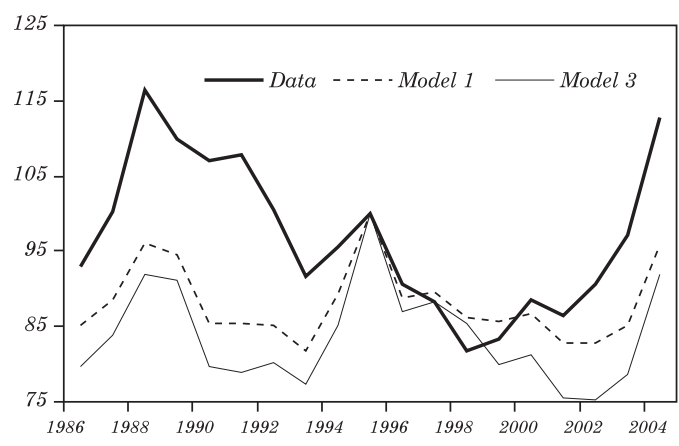

B. Foreign Lending Spread

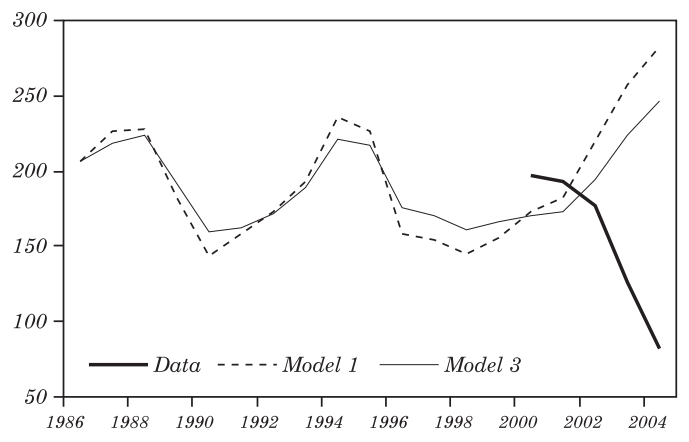

Source: J.P. Morgan's EMBI Global; author's computations.

a.Real exchange rate is measured as the ratio between the price of exportable goods and the price of nontradable goods. Foreign lending spread corresponds to the differential between the domestic interest rate and the foreign interest rate.

\subsection{Households}

Households solve the same problem as in model 2, so their firstorder conditions are given by equations (29)-(37).

\subsection{Firms}

Both firms solve the same problem as in model 3. Their first-order conditions are thus given by equations (42) and (43) for the nontradable firm and by equations (44) and (45) for the export firm. 


\subsection{Competitive Equilibrium}

Given $b_{0}, k_{0}^{X}$, and $k_{0}^{N}$ and shocks' processes $\left(\varepsilon_{t}^{R}, \varepsilon_{t}^{P_{X}}, \varepsilon_{t}^{X}, \varepsilon_{t}^{N}, \Psi_{t}, \tau_{t}^{X}\right.$, $\tau_{t}^{N}$ ), a competitive equilibrium corresponds to sequences of allocations $\left.\left\{c_{t}^{M}, c_{t}^{N}, h_{t}, i_{t}^{X}, i_{t}^{N}, k_{t+1}^{X}, k_{t+1}^{N}, b_{t+1}\right\}\right|_{t=0} ^{\infty},\left.\left\{h_{t}^{f X}, h_{t}^{f N}, k_{t}^{f X}, k_{t}^{f N}\right\}\right|_{t=0} ^{\infty}$ and prices $\left.\left\{P_{t}^{X}, P_{t}^{N}, q_{t}^{X}, q_{t}^{N}, w_{t}, R_{t}\right\}\right|_{t=0} ^{\infty}$ such that:

-Given $b_{0}, k_{0}^{X}, k_{0}^{N}$, prices, and shocks' processes, $\left\{c_{t}^{M}, c_{t}^{N}, h_{t}, i_{t}^{X}\right.$, $\left.i_{t}^{N}, k_{t+1}^{X}, k_{t+1}^{N}, b_{t+1}\right\}\left.\right|_{t=0} ^{\infty}$ solve the households' problem;

-Given prices and shocks' processes, $\left.\left\{h_{t}^{f X}, k_{t}^{f X}\right\}\right|_{t=0} ^{\infty}$ solve firm X's problem;

—Given prices and shocks' processes, $\left.\left\{h_{t}^{f N}, k_{t}^{f N}\right\}\right|_{t=0} ^{\infty}$ solve firm N's problem;

- Market-clearing conditions are satisfied: $c_{t}^{N}=y_{t}^{N}, k_{t}^{X}=k_{t}^{f X}$, $k_{t}^{N}=k_{t}^{f N}$, and $h_{t}=h_{t}^{f X}+h_{t}^{f N}$; and

- The resource constraint is satisfied:

$R_{t} b_{t}+P_{t}^{X} Y_{t}^{X}-c_{t}^{M}-i_{t}^{X}-i_{t}^{N}-\gamma b_{t+1}=0$.

\subsection{Steady State and Calibration}

The self-financing requirement is set as in model 2 and the labor wedges are set as in model 3 , with the nontradable wedge about one percentage point above the export wedge. The other parameters and macroeconomic ratios remain as in model 1 (see table 3).

\subsection{Simulations}

As before, $\Psi_{t}, \tau_{t}^{X}$ and $\tau_{t}^{N}$ are deduced and introduced as shocks to make the model replicate the real net exports and sectoral output in the data between 1986 and 2004. The model is simulated for these shocks and the ones in model 1 . Table 10 shows that the new $\Psi_{t}$ presents roughly the same moments as in model 2 , while the new wedges are slightly less persistent, but more volatile than in model 3, particularly the nontradable wedge. The innovations to both wedges are highly correlated, suggesting that the export wedge is no longer reducing the reallocation of labor across sectors, as the external borrowing constraint does it.

As in model 3, the innovations to the nontradable wedge are negatively correlated to productivity in both sectors, but now they 


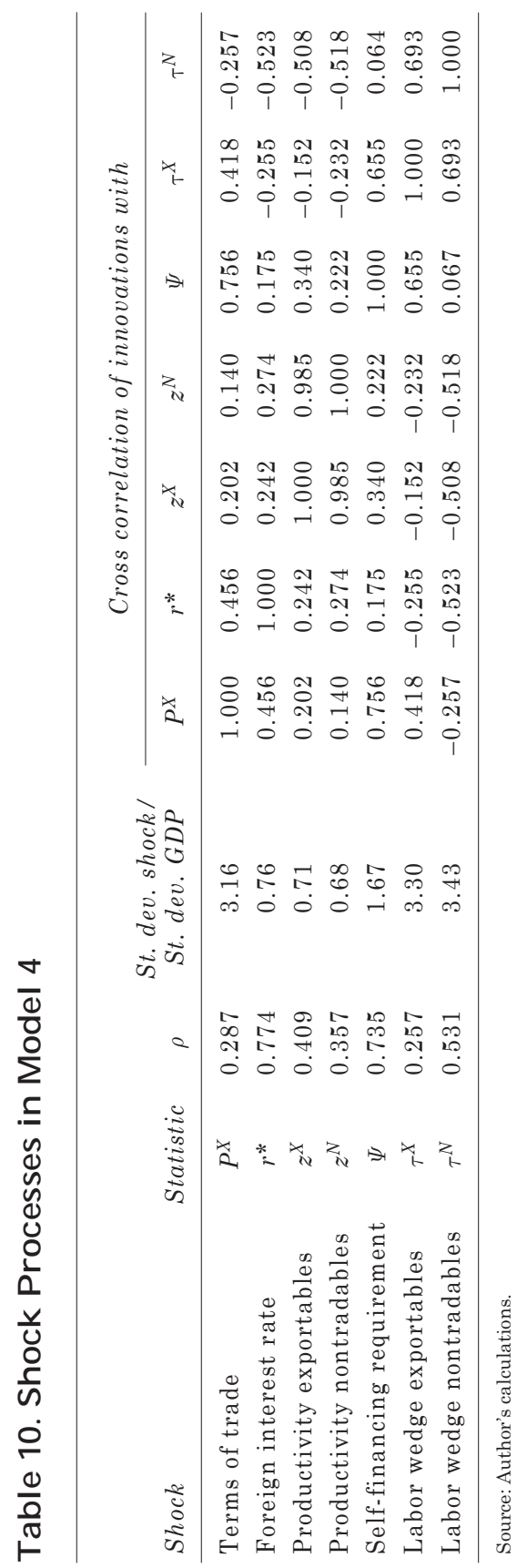


are also negatively correlated to the terms of trade and roughly uncorrelated to $\Psi_{t}$. The innovations to the export wedge are no longer as correlated with the terms of trade, but rather correlate more strongly with $\Psi_{t}$. The lower (but still high) correlation with $P_{t}^{X}$ shows that although the external credit constraint reduces the incentive for labor reallocation across sectors, the wedge is still playing some role in the process. There could also be a spurious correlation, as the innovations to $\Psi_{t}$ and $P_{t}^{X}$ are highly cross-correlated.

Figure 8, panel A, shows that the labor-financing wedge does not change how the external borrowing constraint affects households, since the self-financing requirement and borrowing constraint multiplier follow a path similar to model 2. Although the new nontradable wedge is more volatile than in model 3, it presents roughly the same path as before: it falls continuously between 1991 and 1998, rises suddenly in 1999, and remains high until 2004 (see panel B). The new export wedge, however, is more similar to the nontradable wedge, suggesting that it is more representative of the cost of domestic financing than in model 3.

The two frictions seem to be related because both wedges follow a similar path to the external borrowing constraint multiplier, with a cross-correlation of 0.7. According to the appendix, a high correlation between $\tau_{t}^{j}$ and $\mu_{t}$ suggests that firm $j$ 's cost of financing will vary not only with the domestic interest rate, but also with additional direct changes in its specific lending spread.

Table 11 presents the moments for model 4, which match those of the real net exports and sectoral output in the data by construction. Relative to models 2 and 3, model 4 better reproduces the volatility and procyclicality of aggregate consumption and investment and the countercyclicality and volatility of real net exports. However, although it better replicates the volatility and correlation with output of hours of work in the export and nontradables sectors, it does so at the cost of overestimating the volatility and procyclicality of total work hours.

Figure 9 shows that model 4 replicates aggregate consumption better than model 2, as it replicates consumption of nontradable goods in the data by construction. It also better replicates the path of investment and consumption of importable goods, which is required to generate countercyclical real net exports. With regard to total work hours, model 4 underestimates employment in 1991, when the borrowing constraint multiplier and wedges were highest, and overestimates employment in 1997 and 1998, when both were 


\section{Figure 8. Chile: Self-Financing Requirement and Labor-Financing Wedges}

\section{A. Self-financing requirement}

and extenal borrowing constraint multiplier for models 2 and 4

Self-financing requirement

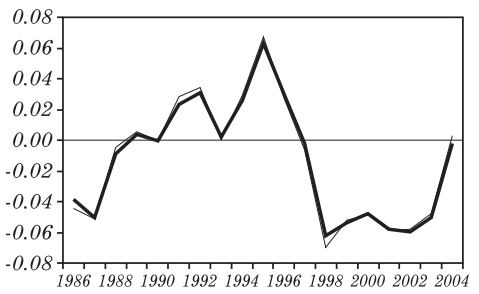

Borrowing constraint multiplier

- Model 4 (left scale)

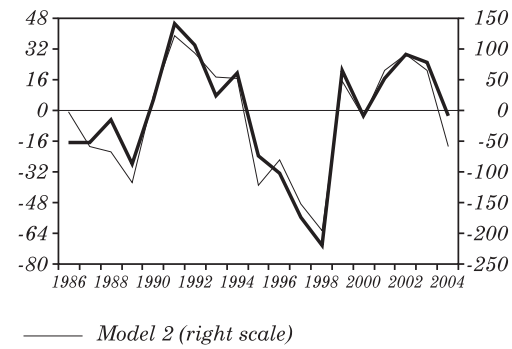

B. Labor-financing wedges for models 3 and 4

Nontradable firm's labor-financing wedge

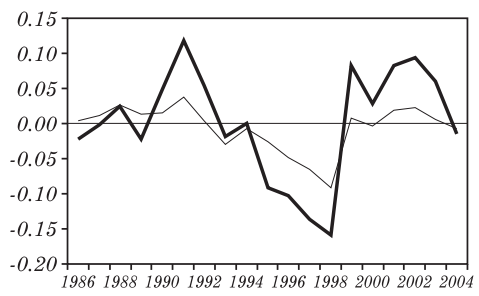

Exportable firm's labor-financing wedge

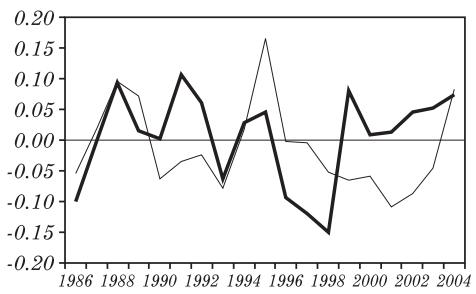

C. Self-financing requirement and extenal borrowing constraint multiplier for model 4 and reduced-friction model

Self-financing requirement

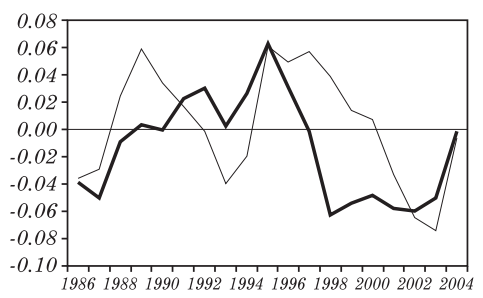

Borrowing constraint multiplier

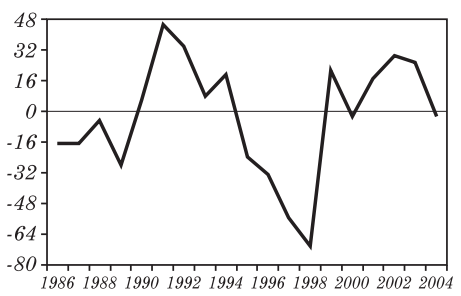




\section{Figure 8. (continued)}

D. Labor-financing wedges

for model 4 and reduced-friction model

Nontradable firm's

labor-financing wedge

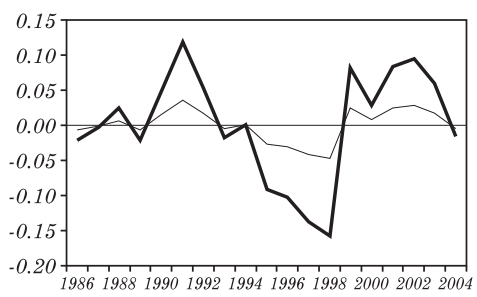

Exportable firm's labor-financing wedge

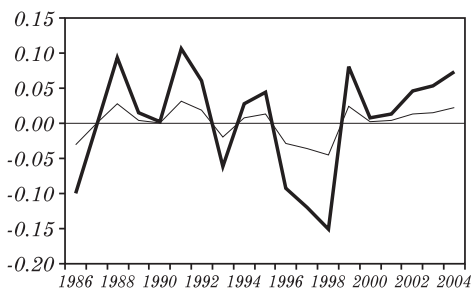

Reduced Frictions

Source: Author's calculations.

lowest. Since the procyclical labor demand generated by the laborfinancing wedge more than offset the countercyclical labor supply generated by the external borrowing constraint, employment becomes more procyclical and volatile than in the data, particularly in the nontradables sector.

Finally, figure 10 shows that model 4 does a better job of replicating the paths of the real exchange rate and the external lending spread than the previous specifications. In particular, model 4 better captures the real appreciation between 1995 and 2000, as well as the real depreciation thereafter, although not before 1995 . The fall in the foreign lending spread, however, is much smaller than in the data because the borrowing constraint multiplier, $\mu_{t}$, is very small in steady state.

This exercise suggests that an adequate characterization of Chile's business cycles since the mid-1980s-and probably of the business cycles of most middle-income countries-should consider the two frictions introduced in model 4, namely, limited access to the external capital market and asymmetric financing opportunities across tradables and nontradables sectors. The former can explain the high procyclicality and volatility of investment and importable goods consumption, as well as the countercyclicality of the real net exports. The latter can explain the high procyclicality and volatility of work hours and nontradable goods consumption, which results in a better characterization of aggregate consumption when combined with the more procyclical and volatile consumption of importable goods. 


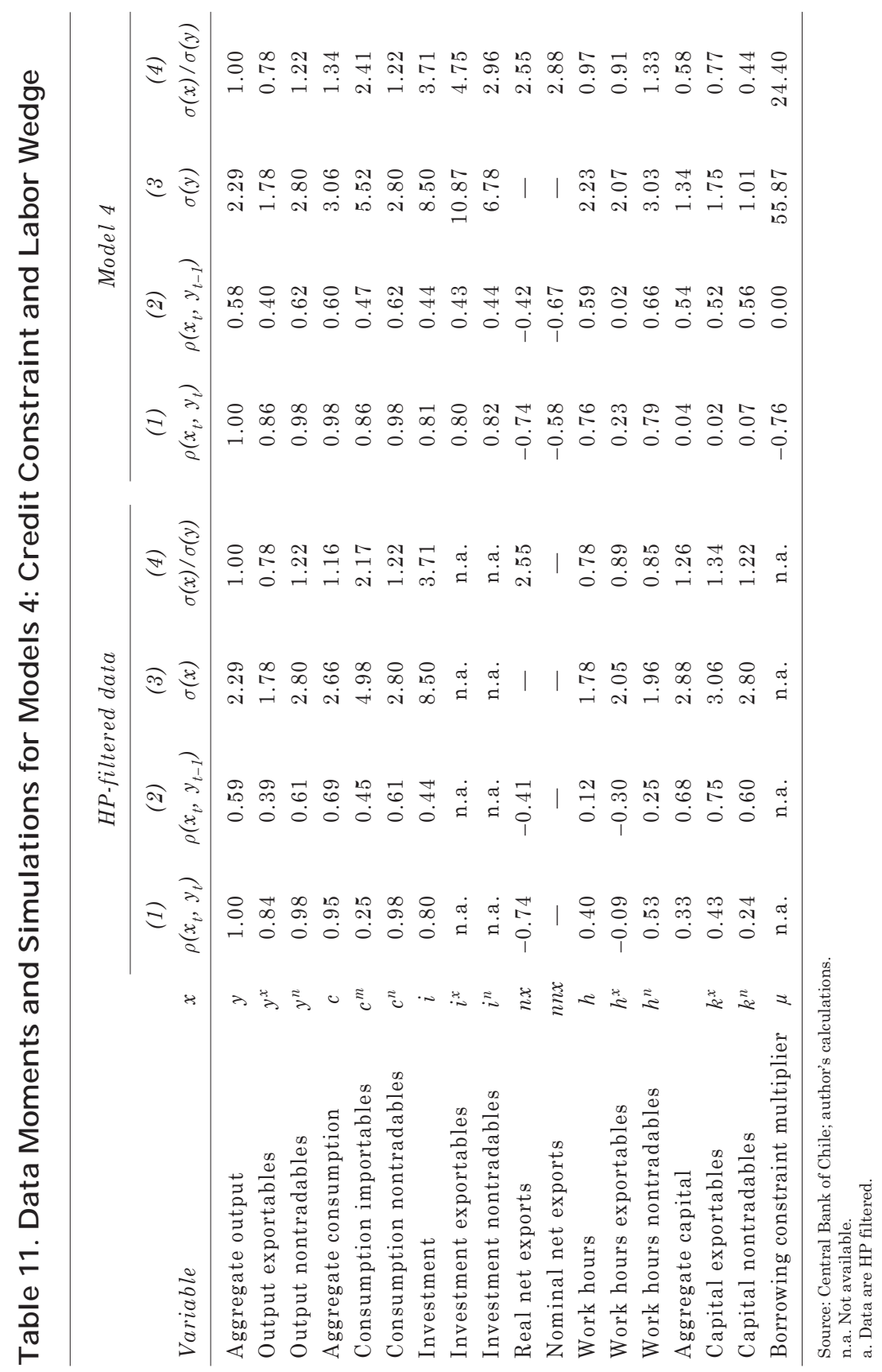




\section{Figure 9. Data and Model 2 and Model 4 Simulations}

Real GDP

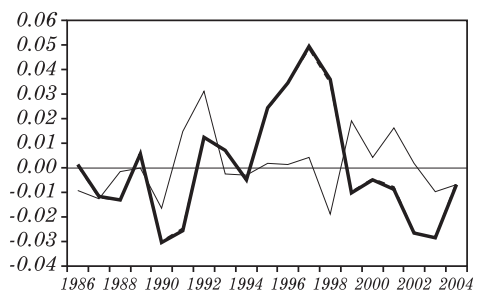

Aggregate investment

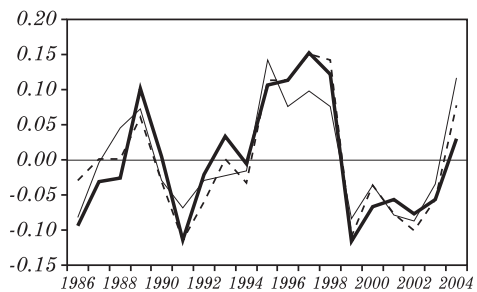

Real GDP exportables

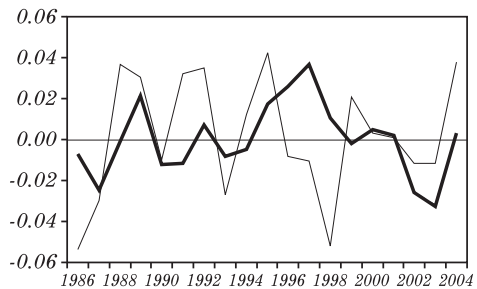

Consumption of importables

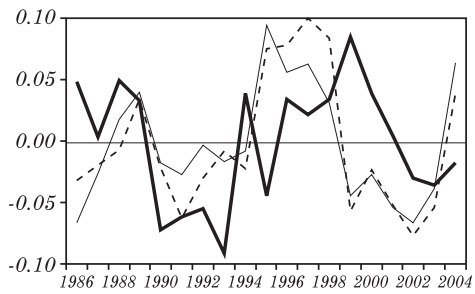

Aggregate consumption

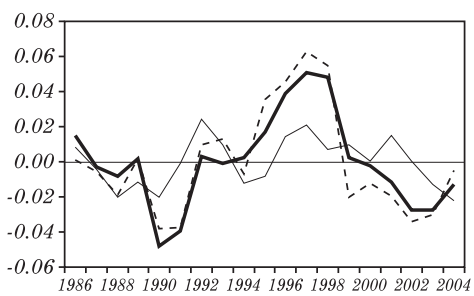

Real net exports

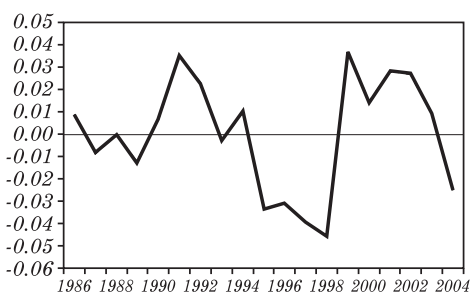

Real GDP and consumption of nontradables

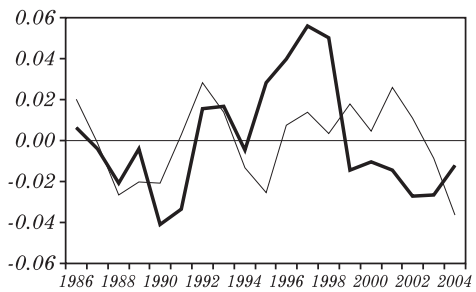

Total hours of work

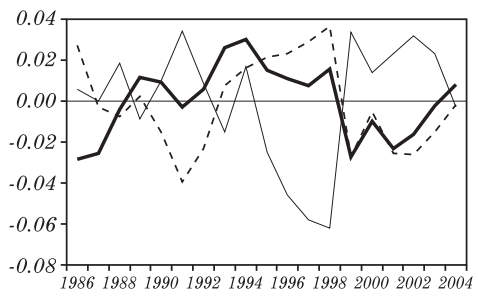


Figure 9. (continued)

Hours of work in exportables

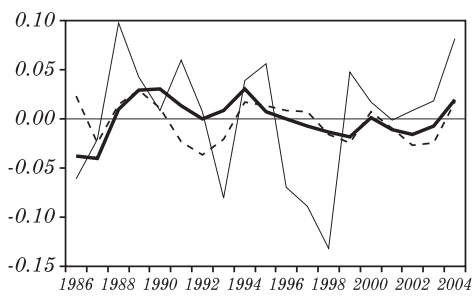

Investment in exportables

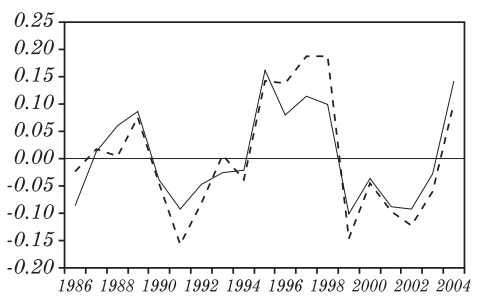

External debt

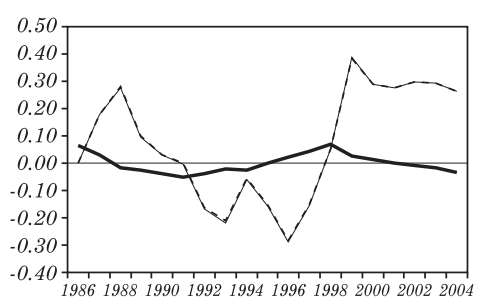

Capital stock

of exportables

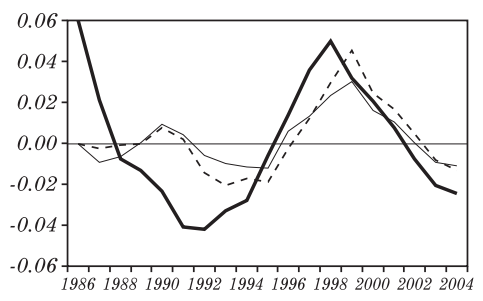

Hours of work in nontradables

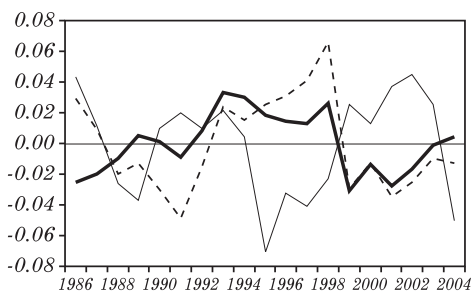

Investment in nontradables

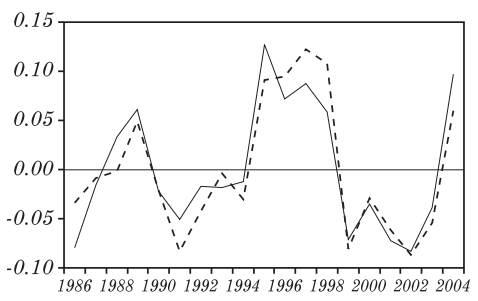

Aggregate capital stock

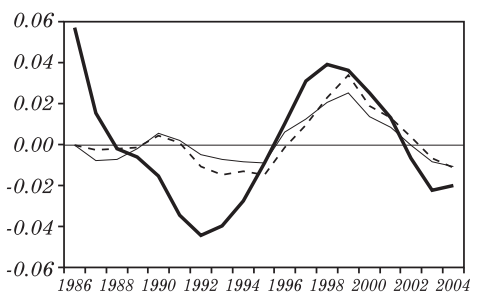

Capital stock of nontradables

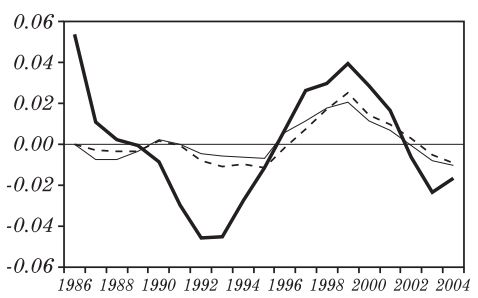


Figure 10. Real Exchange Rate and Foreign Lending Spread ${ }^{\mathrm{a}}$

A. Real Exchange Rate

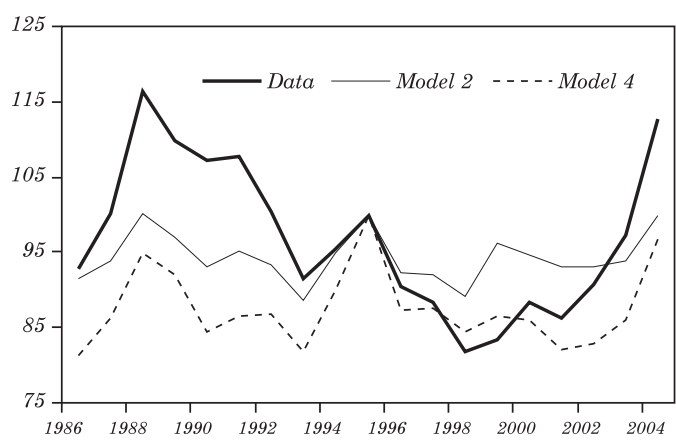

B. Foreign Lending Spread

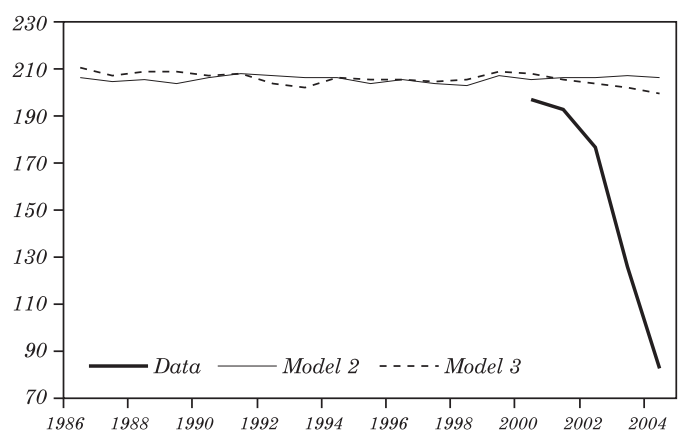

Source: J.P. Morgan's EMBI Global; author's computations.

a.Real exchange rate is measured as the ratio between the price of exportable goods and the price of nontradable goods. Foreign lending spread corresponds to the differential between the domestic interest rate and the foreign interest rate. 


\subsection{Lower Incidence of Frictions}

This study does not endogenize the source of the market imperfections to draw policy implications, but rather presents a simulated scenario for a lower incidence of frictions to see what would have been the cyclical properties of an economy with better access to foreign and domestic financing. The self-financing requirement is made more procyclical and volatile to get a constant borrowing constraint multiplier over time, and the standard deviations of the sector-specific labor-financing wedges are reduced to 30 percent of its value in the data. Figure 8, panel $\mathrm{C}$, shows that $\Psi_{t}$ should have been higher than in model 4 between 1996 and 2001, but lower in 2002 and 2003.

Table 12 presents the autocorrelations, standard deviations, and cross-correlations of innovations in this new set of shocks. It shows that to obtain a higher degree of risk sharing between domestic households and foreign lenders, $\Psi_{t}$ has to be less persistent, but more volatile, and it should be more correlated to the terms of trade and productivity in both sectors. Figure 11 and table 13 show that with a lower incidence of frictions, the cyclical properties of the economy would be qualitatively similar to the frictionless case. The volatility of consumption and investment would have been smaller, and total work hours and exportable goods output would have been more procyclical and more volatile, resulting in more procyclical and less volatile real net exports. This scenario would have been welfare improving, as households value consumption smoothing. 


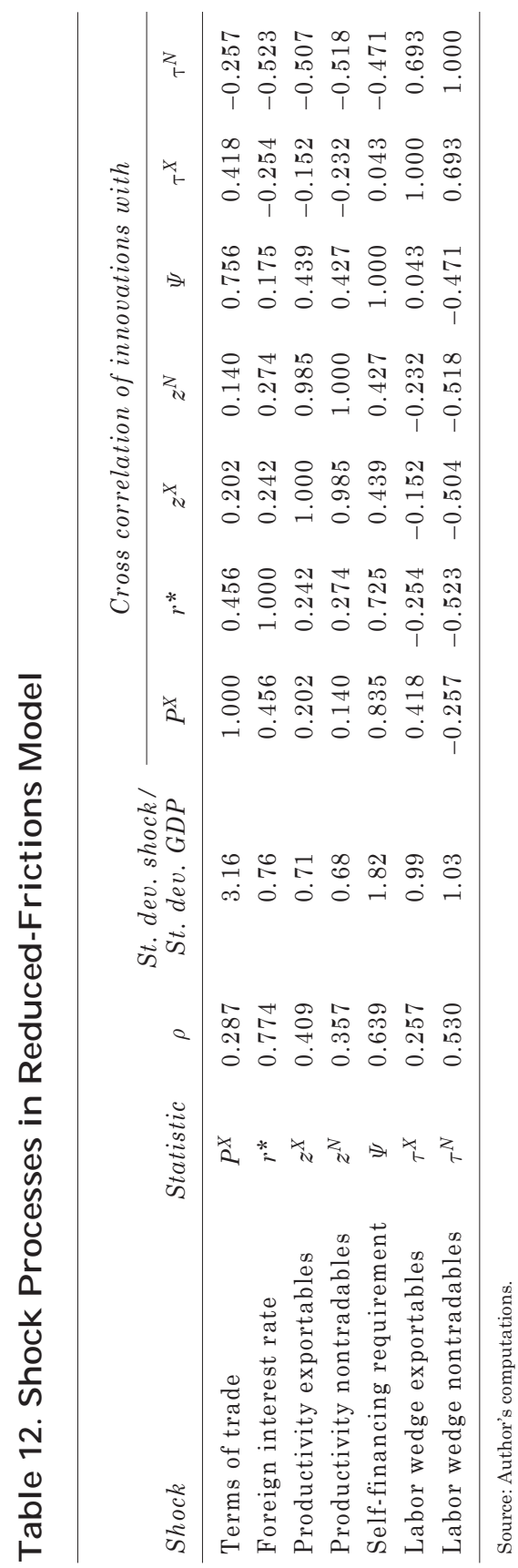




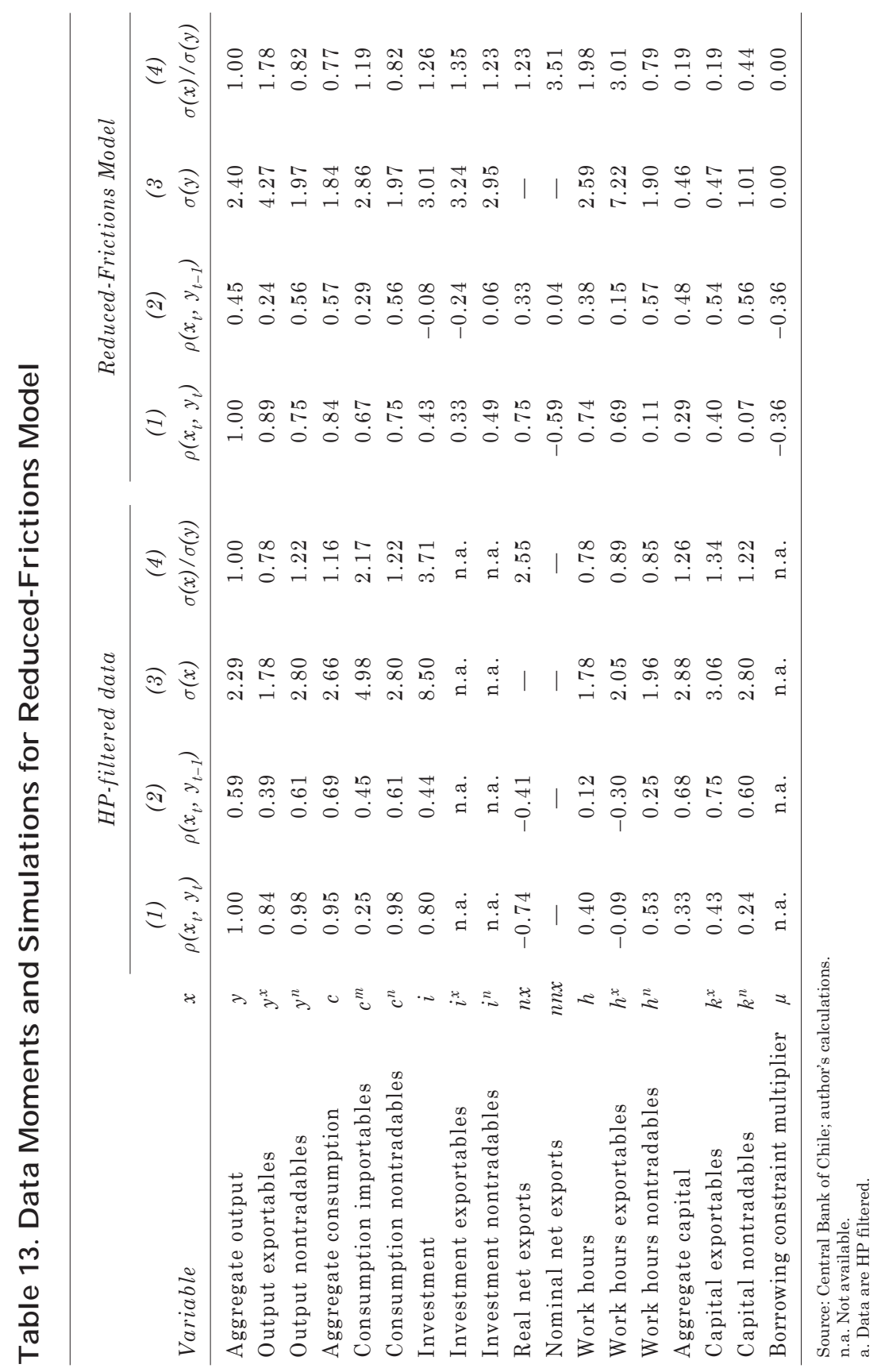




\section{Figure 11. Data, Model 4, and Reduced-Frictions Model}

Real GDP

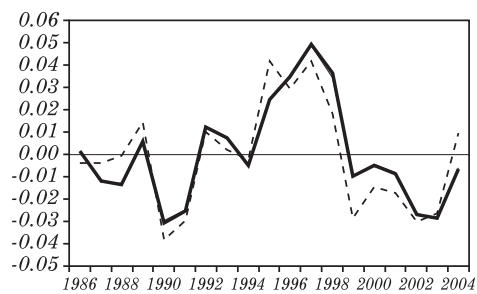

Aggregate investment

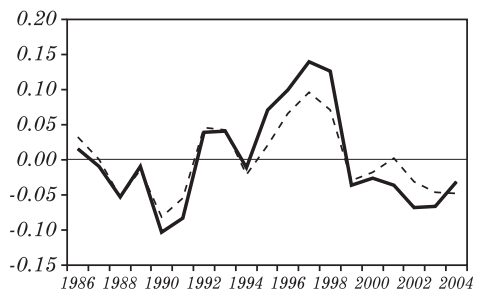

Real GDP exportables

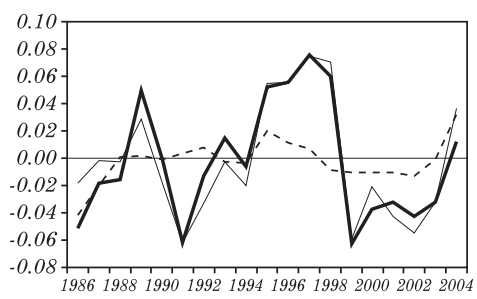

Consumption of importables

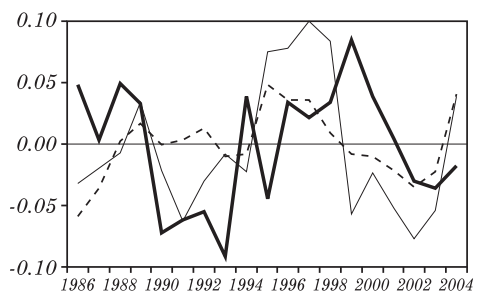

Aggregate consumption

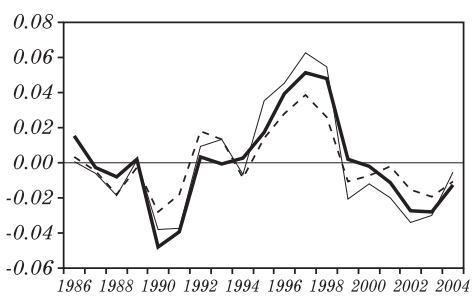

Real net exports

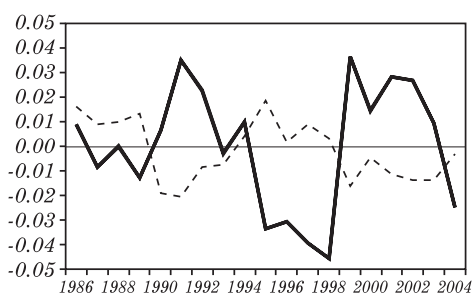

Real GDP and consumption of nontradables

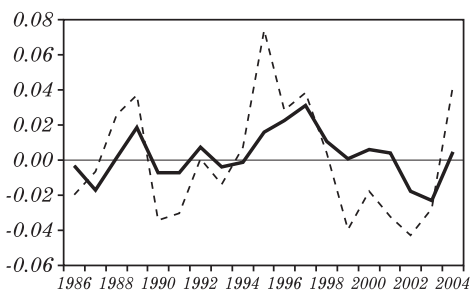

Total hours of work

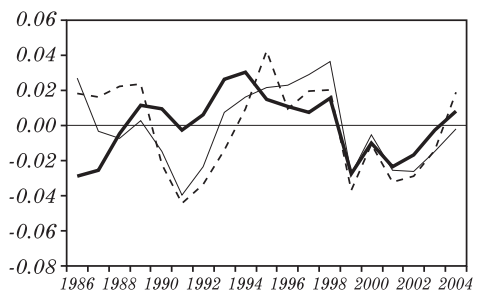


Figure 11. (continued)

Hours of work in exportables

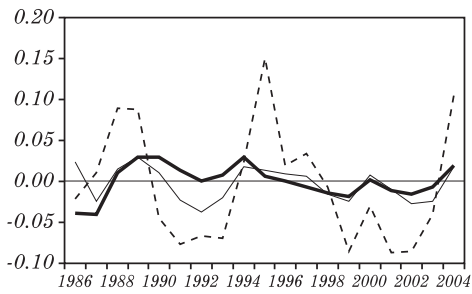

Investment in exportables

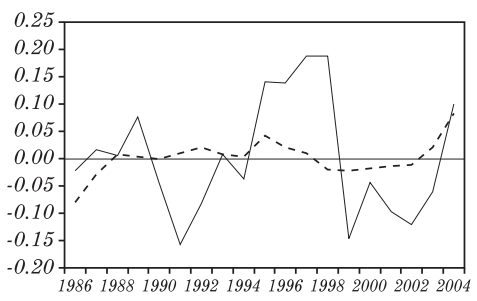

External debt

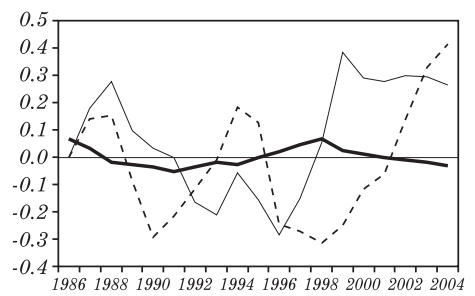

Capital stock of exportables

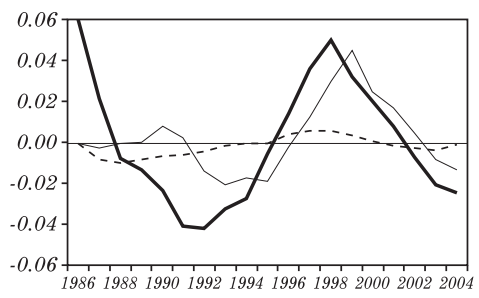

Hours of work in nontradables

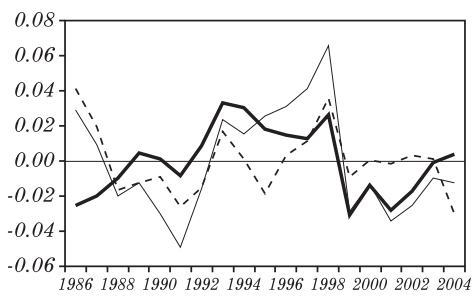

Investment in nontradables

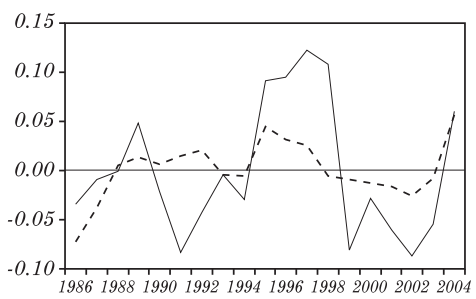

Aggregate capital stock

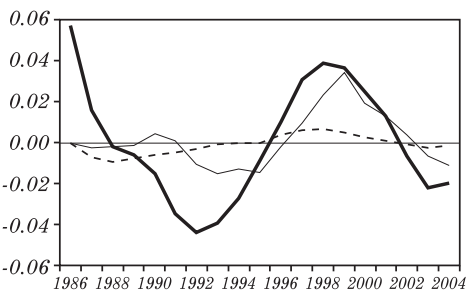

Capital stock of nontradables

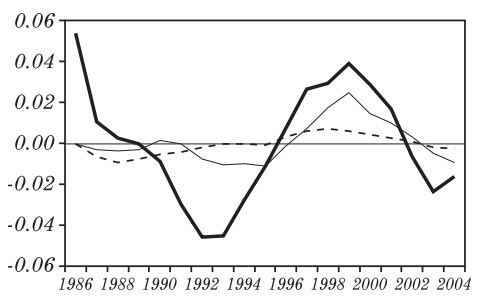




\section{Conclusions}

Business cycles in middle-income countries are characterized by highly procyclical and volatile consumption and by countercyclical and volatile real net exports. Standard DSGE small open economy models have failed to reproduce these features, because they predict excessive consumption smoothing and procyclical real net exports. Earlier studies approach the problem either by increasing the persistence of shocks or by lowering the intertemporal elasticity of substitution.

This study shows that the problem can be solved without changing preferences or the shocks' persistence, but rather by considering two market frictions that are relevant for middle-income countries: imperfect access to the foreign capital market and asymmetric financing opportunities across tradable and nontradable firms. The former, identified as an external borrowing constraint, generates more procyclical and volatile investment and consumption of importable goods, reduces the excessive reallocation of labor between the export and nontradables sectors, lowers the volatility of exportable output, and produces countercyclical and volatile real net exports. However, it predicts countercyclical rather than procyclical labor supply and employment, and it does not increase enough the volatility of nontradable goods consumption.

The asymmetric financing opportunities across sectors, identified as sector-specific labor-financing wedges, create procyclical fluctuations in labor demand, which increases the procyclicality and volatility of employment, nontradable goods output, and aggregate consumption. It does not increase the procyclicality and volatility of investment and importable goods consumption, nor does it produce countercyclical real net exports. The two frictions thus seem to complement each other, as they help the model to reproduce different features of the data. The exercise considering both frictions together suggests that an adequate characterization of Chile's business cycles since the mid-1980s, and probably the cycles of most middle-income countries, should consider the role played by these two frictions in the origin and amplification of the domestic cycles.

Finally, although this study does not endogenize the source of the market imperfections to draw policy implications, it presents a simulated scenario for a lower incidence of frictions to see the cyclical properties of an economy with better access to foreign and domestic financing. This exercise shows that the self-financing requirement has to be more procyclical, and more correlated to 
the terms of trade and productivity, to produce a higher degree of risk sharing between domestic households and foreign lenders. The cyclical properties of this economy would be qualitatively similar to a frictionless economy; the volatility of consumption and investment would be smaller; and employment and exportable goods output would be more procyclical and volatile, resulting in procyclical and less volatile real net exports. This would improve welfare since households value consumption smoothing. 
ApPendix

\section{Labor-Financing Wedges Based on Collateral Constraints}

Consider a small economy that is perfectly open to the world in goods, but faces household-specific external borrowing constraints defined as the requirement to self-finance a fraction of their expenditures, $\Psi_{t}$, with their current income at date $t$ (equation 27). There are four types of agents: foreign lenders, domestic households, domestic firms, and domestic banks. Foreign lenders set the borrowing constraints on the households. Households own the firms and banks, consume the $N$ good, buy the $M$ good for consumption and investment, and supply $h$ and $k$ to the firms. They supply funds to the domestic banks within the period at the rate of return $R_{t}$, and demand funds from the firms within the period at the same rate.

Both the export and the nontradable firms demand $h$ and $k$ for production. They pay wages before production is realized, thus facing a credit-in-advance constraint. The timing is as follows. Firm $j$ get credit from the banks at the beginning of each period at a rate of return, $R_{t}^{l j}$, but it pays wages only at the end of the period, just before production is materialized. It can thus lend its loan to the households within the period at the rate of return, $R_{t}$, which results in a net cost of the loan of $R_{t}^{l j}-R_{t} \geq 0$.

Banks receive deposits from households within the period at the rate of return, $R_{t}$, and lend to the firms subject to collateral constraints. The collateral is the fraction of the firm's output they can seize, which results in a lending rate of $R_{t}^{l j} \geq R_{t}$ with $j=X, N$. All the lending costs are rebated to the households in a lump sum, so that the resource constraint does not change. The economy follows a balanced growth path, and population is constant. In the following discussion, the model is set in stationary form.

\section{Households}

The households' problem is the same as in model 2, so their firstorder conditions are given by equations (29)-(37).

\section{Firms}

Both firms get credit from banks at the beginning of each period and repay it at the end of the period. They lend their loans within the 
period to the households at the rate of return $R_{t}$. As $R_{t}^{l j} \geq R_{t}$, their optimal decision is to hold just the necessary credit to pay wages in each period, satisfying the credit-in-advance constraint in equality:

$z_{t}^{f j}=w_{t} h_{t}^{f j}$

for $j=X, N$, where $z_{t}^{j}$ is the credit received by firm $j$. The firm's total cost of production is given by:

$w_{t} h_{t}^{f j}\left(1+R_{t}^{l j}-R_{t}\right)+q_{t}^{j} k_{t}^{f j}$

for $j=X, N$. Firm $j$ chooses $h_{t}^{f j}, k_{t}^{f j}$ to maximize profits. Its first-order conditions are as follows:

$w_{t}\left(1+R_{t}^{l j}-R_{t}\right)=\left(1-\alpha_{j}\right) P_{t}^{j} \exp \left(\varepsilon_{t}^{j}\right)\left(k_{t}^{f j}\right)^{\alpha_{j}}\left(h_{t}^{f j}\right)^{-\alpha_{j}}$ and

$q_{t}^{j}=\alpha_{j} P_{t}^{j} \exp \left(\varepsilon_{t}^{j}\right)\left(h_{t}^{f j}\right)^{\left(1-\alpha_{j}\right)}\left(k_{t}^{f j}\right)^{\left(\alpha_{j}-1\right)}$,

for $j=X, N$.

\section{Banks}

The banking industry is perfectly competitive. Banks take deposits from households and lend them to the firms, subject to collateral constraints. The collateral is a fraction, $\Omega_{t}^{j}$, of firm j's output that banks can seize at the end of each period. They thus face the following constraint when allocating loans:

$\Omega_{t}^{j} Y_{t}^{j} \geq z_{t}^{j}$

for $j=X, N$. The banks' problem is to choose the allocation $\left\{z_{t}^{X}, z_{t}^{N}\right\}$ in each period to maximize profits. Their first-order conditions are

$$
R_{t}^{l X}-R_{t}=\eta_{t}^{X} \text { and }
$$


$R_{t}^{l N}-R_{t}=\eta_{t}^{N}$

where $\eta_{t}^{X}$ and $\eta_{t}^{N}$ are the Lagrange multipliers on equation (50) for $X$ and $N$, respectively.

\section{Competitive Equilibrium}

Given initial values of $b_{0}, k_{0}^{X}$, and $k_{0}^{N}$, and shocks' processes $\left(\varepsilon_{t}^{R}, \varepsilon_{t}^{P_{X}}\right.$, $\left.\varepsilon_{t}^{X}, \varepsilon_{t}^{N}, \Psi_{t}, \Omega_{t}^{X}, \Omega_{t}^{N}\right)$, a competitive equilibrium corresponds to sequences of allocations $\left.\left\{c_{t}^{M}, c_{t}^{N}, h_{t}, i_{t}^{X}, i_{t}^{N}, k_{t+1}^{X}, k_{t+1}^{N}, b_{t+1}, z_{t}^{X}, z_{t}^{N}\right\}\right|_{t=0} ^{\infty},\left\{h_{t}^{f X}, k_{t}^{f X}\right.$, $\left.z_{t}^{f X}, k_{t}^{f N}, h_{t}^{f N}, z_{t}^{f N}\right\}\left.\right|_{t=0} ^{\infty}$ and prices $\left.\left\{P_{t}^{X}, P_{t}^{N}, q_{t}^{X}, q_{t}^{N}, w_{t}, R_{t}, R_{t}^{l X}, R_{t}^{l N}\right\}\right|_{t=0} ^{\infty}$ such that:

-Given $b_{0}, k_{0}^{X}, k_{0}^{N}$, prices, and shocks' processes, $\left\{c_{t}^{M}, c_{t}^{N}, h_{t}, i_{t}^{X}\right.$, $\left.i_{t}^{N}, k_{t+1}^{X}, k_{t+1}^{N}, b_{t+1}\right\}\left.\right|_{t=0} ^{\infty}$ solve the households' problem;

—Given prices and shocks' processes, $\left.\left\{h_{t}^{f X}, k_{t}^{f X}, z_{t}^{f X}\right\}\right|_{t=0} ^{\infty}$ solve firm X's problem;

-Given prices and shocks' processes, $\left.\left\{h_{t}^{f N}, k_{t}^{f N} z_{t}^{f N}\right\}\right|_{t=0} ^{\infty}$ solve firm N's problem;

-Given prices and shocks' processes, $\left.\left\{z_{t}^{X}, z_{t}^{N}\right\}\right|_{t=0} ^{\infty}$ solve bank's problem;

-Market-clearing conditions are satisfied: $c_{t}^{N}=y_{t}^{N}, k_{t}^{X}=k_{t}^{f X}$, $k_{t}^{N}=k_{t}^{f N}, h_{t}=h_{t}^{f X}+h_{t}^{f N}, z_{t}^{X}=z_{t}^{f X}$, and $z_{t}^{N}=z_{t}^{f N}$; and

-The resource constraint is satisfied:

$R_{t} b_{t}+P_{t}^{X} Y_{t}^{X}-c_{t}^{M}-i_{t}^{X}-i_{t}^{N}-\gamma b_{t+1}=0$.

\section{Equivalence to Labor Financing Wedges}

The reduced form of this model is the same as for model 4, with $\tau_{t}^{j}=\eta_{t}^{j}=R_{t}^{l X}-R_{t}$. Thus, the sector-specific labor-financing wedges deduced in models 3 and 4 can be interpreted as the spread over the domestic interest rate that each firm pays on its credit from the domestic banks. 


\section{REFERENCES}

Aguiar, M. and G. Gopinath. 2004. "Emerging Market Business Cycles: The Cycle Is the Trend.” Working paper 04-4. Federal Reserve Bank of Boston.

Albuquerque, R. and H. Hopenhayn. 2004. "Optimal Lending Contracts and Firm Dynamics." Review of Economic Studies 71(2): 285-315.

Alvarez, F. and J. Jermann. 2000. "Efficiency, Equilibrium, and Asset Pricing with Risk of Default." Econometrica 68(4): 775-98.

Atkeson, A. 1991. "International Lending with Moral Hazard and Risk of Repudiation." Econometrica 59(4): 1069-89.

Atkeson, A. and V. Rios-Rull. 1996. "The Balance of Payments and Borrowing Constraints: An Alternative View of the Mexican Crisis." Journal of International Economics 41(3-4): 331-49.

Barrionuevo, J. 1993. "Asset Pricing in the International Economy." Working paper 93/15. Washington: International Monetary Fund. Bernanke, B. and M. Gertler. 1989. "Agency Costs, Net Worth, and Business Fluctuations." American Economic Review 79(1): $14-31$.

Bulow, J. and K. Rogoff. 1989. "A Constant Recontracting Model of Sovereign Debt." Journal of Political Economy 97(1): 155-78.

Caballero, R. 2000. "Macroeconomic Volatility in Latin America: A View and Three Case Studies." Working paper 7782. Cambridge, Mass.: National Bureau of Economic Research.

. 2002. "Coping with Chile's External Vulnerability: A Financial Problem." Economía Chilena 5(1): 11-36.

Caballero, R., K. Cowan, E. Engel and A. Micco. 2004. "Effective Labor Regulation and Microeconomic Flexibility.” Working paper 10744. Cambridge, Mass.: National Bureau of Economic Research.

Caballero, R. and A. Krishnamurthy. 2001. "International and Domestic Collateral Constraints in a Model of Emerging Market Crises." Journal of Monetary Economics 48(3): 513-48.

Chari, V.V., P. Kehoe, and E. McGrattan. 2003. "Business Cycles Accounting." Working paper 625. Federal Reserve Bank of Minneapolis.

Correia, I., J. Neves, and S. Rebelo. 1995. "Business Cycles in a Small Open Economy." European Economic Review 39(6): 1089-113.

Domeij, D. 2006. "The Labor-Supply Elasticity and Borrowing Constraints: Why Estimates Are Biased." Review of Economics Dynamics 9(2): 242-62. 
Eaton, J. and M. Gersovitz. 1981. "Debt with Potential Repudiation: Theoretical and Empirical Analysis." Review of Economic Studies 48(2): 289-309.

Gallego, F., K. Schmidt-Hebbel, and L. Serven. 2005. "General Equilibrium Dynamics of Foreign Shocks and Policy Changes in Chile." In General Equilibrium Models for the Chilean Economy, edited by R. Chumacero and K. Schmidt-Hebbel. Santiago: Central Bank of Chile.

García, C., P. García, I. Magendzo, and J. Restrepo. 2005. "A MediumSized Macroeconometric Model of the Monetary Transmission Mechanism in Chile." In General Equilibrium Models for the Chilean Economy, edited by R. Chumacero and K. Schmidt-Hebbel. Santiago: Central Bank of Chile.

Greenwood, J., Z. Hercowitz, and G. Hoffman. 1988. "Investment, Capacity Utilization, and the Real Business Cycle." American Economic Review 78(3): 402-17.

Holmström, B. and J. Tirole. 1998. "Private and Public Supply of Liquidity." Journal of Political Economy 106(1): 1-40.

Jeske, K. 2001. "Private International Debt with Risk of Repudiation." Working paper 2001-16. Federal Reserve Bank of Atlanta.

Kehoe, T. and D. Levine. 1993. "Debt-Constrained Asset Markets." Review of Economic Studies 60(4): 865-88.

Kocherlakota, N. 1996. "Implications of Efficient Risk Sharing without Commitment." Review of Economic Studies 63(4): 595-609.

Kiyotaki, N. and J. Moore. 1997. "Credit Cycles." Journal of Political Economy 105(2): 211-48.

Medina, J.P. 2004. "Endogenous Financial Constraints: Persistence and Interest Rates Fluctuations." Working paper 290. Santiago: Central Bank of Chile.

Mendoza, E. 1995. "The Terms of Trade, the Real Exchange Rate, and Economic Fluctuations." International Economic Review 36(1): 101-37.

2001. "Credit, Prices, and Crashes: Business Cycles with a Sudden Stop.” Working paper 8338. Cambridge, Mass.: National Bureau of Economic Research.

Neumeyer, P. and F. Perri. 2005. "Business Cycles in Developing Economies: The Role of Interest Rates." Journal of Monetary Economics 52(2): 345-80.

Ostry, J. and C. Reinhart. 1992. "Private Savings and Terms of Trade Shocks." IMF Staff Papers 39(3): 495-517. 
Schmitt-Grohé, S. and M. Uribe. 2003. "Closing Small Open Economy Models.” Journal of International Economics 61(1): 163-85.

Stockman, A. and L. Tesar. 1995. "Tastes and Technology in a TwoCountry Model of the Business Cycle: Explaining International Comovements." American Economic Review 85(1): 168-85.

Tornell, A. and F. Westermann. 2002. "Boom-Bust Cycles in MiddleIncome Countries: Facts and Explanations." Working paper 9219. Cambridge, Mass.: National Bureau of Economic Research. . 2003. "Credit Market Imperfections in Middle-Income Countries." Working paper 9737. Cambridge, Mass.: National Bureau of Economic Research. 